\title{
Ratni reporter Vladimir Becić
}
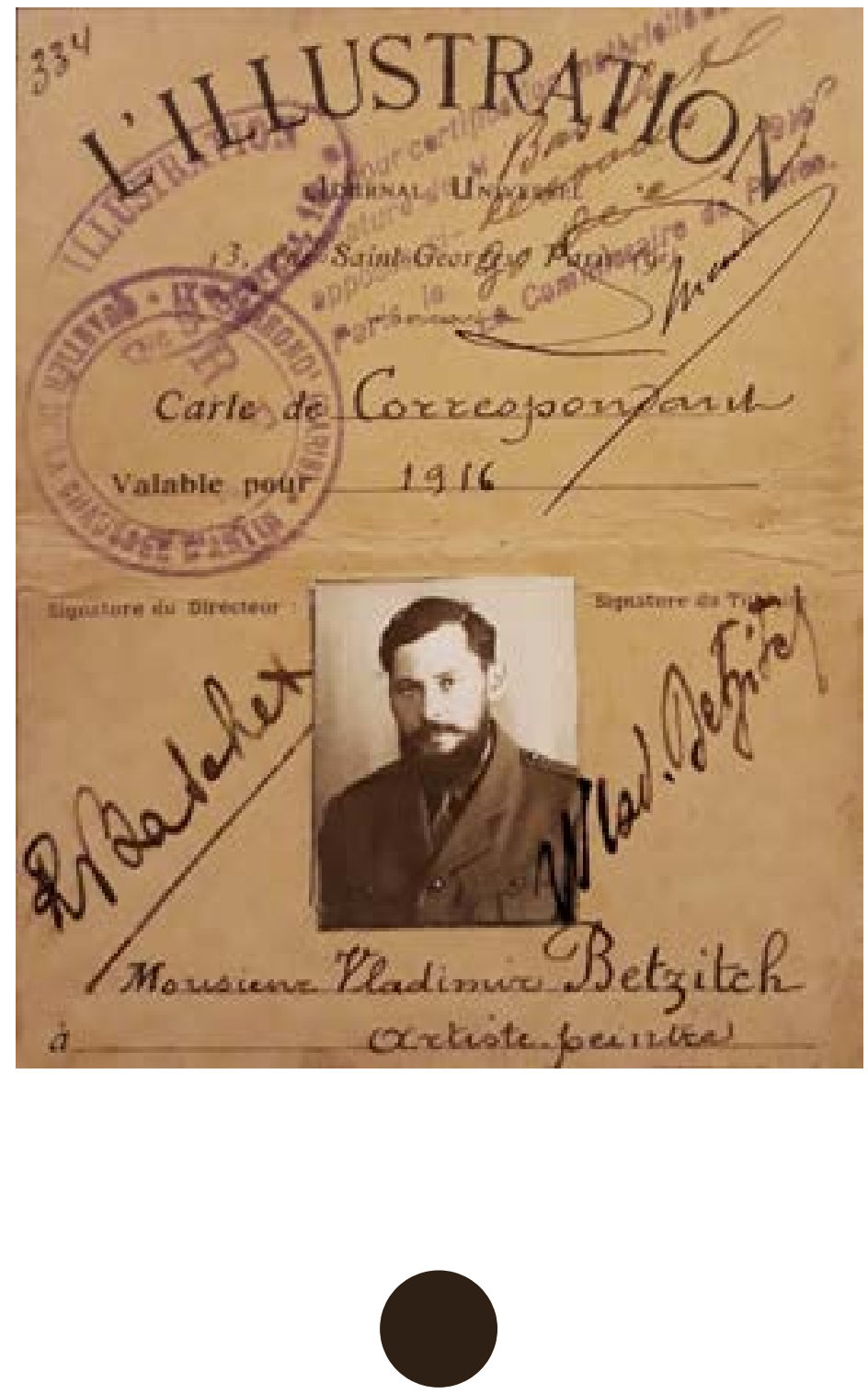

\section{Vladimir Becić, \\ War Correspondent}


PREGLEDNI RAD

Predan: 22.11.2018.

Prihvaćen: 13.12.2018.

DOI: $10.31664 /$ zu.2018.103.04

UDK: 77.044::355.4](497.11)"1914/1918"75Becić, V.

\section{SAŽETAK}

Kada je u ljeto 1914. izbio Prvi svjetski rat, Vladimir Becić kao dobrovoljac se javio u srpsku vojsku. Na proljeće iduće godine postavljen je na dužnost ratnoga slikara u štabu 1. šumadijske divizije. Sudjelujući u masovnome i dramatičnome povlačenju vojske i naroda od Smedereva i Kraljeva, preko Prištine i Prizrena, Crne Gore i Albanije do Jadrana, Becić je fotografirao događaje kojima je svjedočio, pa tako nastaje jedinstvena serija dokumentarnih fotografija, ali i ilustracija koje će godinu poslije objaviti u visokotiražnome pariškom polumjesečniku L'Illustration, postavši redovitim dopisnikom časopisa.

KLJUČNE RIJEČI

Vladimir Becić, Prvi svjetski rat, Kraljevina Srbija,

reportažna ilustracija, reportažna fotografija, L'Illustration

\section{REVIEW ARTICLE}

Received: November 22, 2018

Accepted: December 13, 2018

DOI: $10.31664 / z u .2018 .103 .04$

UDC: 77.044::355.4](497.11)"1914/1918"75Becić, V.

\section{ABSTRACT}

When the First World War broke out in the summer of I9I4, Vladimir Becić voluntarily joined the Serbian army. In the spring next year, he was appointed as a war painter with the Command of the First Sumadija division. Taking part in the massive and dramatic withdrawal of the army and civilians from Smederevo and Kraljevo, through Priština and Prizren, Montenegro and Albania to the Adriatic coast, Becić photographed events he witnessed, thus creating a unique series of documentary photographs, but also illustrations that would be published a year later in the mass-circulation Paris semimonthly L'Illustration, which made him a regular correspondent.

KEYWORDS

Vladimir Becić, World War I, Kingdom of Serbia, press illustration, press photography, L'Illustration
Novinarska iskaznica Vladimira Becića kao ratnog dopisnika magazina L'Illustration.

Vlasništvo obitelji. Presnimka: G. Vranić / Vladimir Becić's press credentials as a war correspondent of the L'Illustration magazine. Owned by the family. Repro photo: G.Vranić

\section{Zvonko Maković}




\section{„TRAŽIM OD VLADE U ZAGREBU MJESTO NASTAVNIKA CRTANJA..."}

U likovnoj kritici i povijesti umjetnosti za četvoricu hrvatskih studenata koji su istodobno studirali na umjetničkoj akademiji u Münchenu druge polovice prvoga desetljeća 20. stoljeća i njegovali iste ili barem vrlo bliske afinitete konstruiran je pojam „Minhenski krug”. Tu četvoricu čine Josip Račić, Vladimir Becić, Miroslav Kraljević i Oskar Herman. Tim se pojmom umjetnost četvorice slikara nastojala pobliže odrediti, ne samo kao generacijsko nego i kao poetičko zajedništvo. Priča o njihovu zajedničkome školovanju nije posve vjerodostojna, jer svaki je od njih u München stigao sam i u drugo vrijeme. Uzme li se činjenica zajedničkoga studiranja u klasi istoga profesora te Hermanovo rano napuštanje linije slikarskog moderniteta Manet-Cézanne, „kojom su krenuli Becić i Kraljević, a za koju možemo pretpostaviti da bi njome krenuo i Račić (...) možemo zaključiti da je cjelina Münchenskog kruga prilično krhka te da se temelji samo na općenitim postavkama slikarske modernosti i činjenici da su svi-neki dulje, a neki kraće-studirali u klasi profesora čiji se izravan utjecaj, u smislu prihvaćanja specifičnih formalno-stilskih elemenata ili određujućih poetičkih usmjerenja, ne može prepoznati". ' Zaista, konstrukcija toga segmenta hrvatske umjetnosti s početka 20. stoljeća, kao neke kompaktne poetičke cjeline, zasnovana je na slabim temeljima pa je umjesnije promatrati sazrijevanje i razvoj svakoga od četvorice „minhenovaca” pojedinačno.

U proljeće 1909. Becić je završio studij na Akademiji i uputio se u Pariz, gdje je godinu dana prije, sa samo dvadeset i tri godine, skončao svoj život Josip Račić. Upisao se na Académie de la Grande Chaumière, a iste godine šalje jedan akvarel na Salon d'Automne, koji je i prihvaćen. Znatiželja mu je velika, energija također. Te 1909. godine nastalo je, među brojnim drugima, i nekoliko njegovih velikih slika, a to su Autoportret s polucilindrom (1909.) i Mrtva priroda (1909.). Prije spomenuta autoportreta naslikao je Becić više njih, no ovo je prvo njegovo zrelo djelo nastalo u tome žanru. I tu se prepoznaje redukcija, svođenje boje na variranje smeđih $\mathrm{i}$ oker tonova s crnim akcentima. Izraz lica je smiren, pogled usmjeren na promatrača, titravi osmijeh koji se jedva nazire ispod nježnih brkova i na lijepo oblikovanim usnama. Samo je Kraljević, ali tri godine kasnije, također u Parizu, naslikao autoportrete takve slikarske uvjerljivosti.

U Parizu Becić, kao i mnogi drugi, posjećuje atelijer Ivana Meštrovića, atelijer koji je generaciji umjetnika koji su ovdje boravili bio važnim sastajalištem, a prije svega mjestom povezivanja i stvaranja važnih strateških ciljeva. Među umjetnicima koji su ovamo dolazili bila je i srpska slikarica Nadežda Petrović, čija je uloga u organizaciji Prve jugoslavenske umjetničke izložbe bila iznimno važna, a na toj je izložbi, kao vrlo mlad, izlagao i Vladimir Becić. Riječ je o velikoj manifestaciji kojom se obilježavala stota obljetnica Prvoga srpskog ustanka i krunidba kralja Petra I. Karađorđevića, a među 458 izložaka devedesetšestorice umjetnika djelo jednog osamnaestogodišnjaka zamijetila je i kritika. ${ }^{2}$ Štoviše,

\section{"I AM ASKING THE GOVERNMENT IN ZAGREB FOR A POSITION OF A DRAWING TEACHER..."}

In visual art criticism and history, four Croatian students who attended the Academy of Arts in Munich in the second half of the first decade of the 2oth century and had the same, or at least very close affinities, were known by the term "the Munich Circle." These four were Josip Račić, Vladimir Becić, Miroslav Kraljević and Oskar Herman. This term was meant to more closely designate the art of the four painters, not just as a generational, but also as a poetic fellowship. The story of their studying together is not completely reliable because each of them arrived in Munich on his own and at a different time. If we take into account the fact that they studied together in the class of the same professor, and Herman's early abandonment of the direction of visual arts modernity Manet-Cézanne, "that was taken by Becić and Kraljević and which, we can assume, would also be taken by Račić (...) we can conclude that the unity of the Munich Circle is rather brittle and that it is based only on general postulates of modernist painting and the fact that all of them-some for longer, and some for a shorter time-studied in the class of a professor whose direct influence, in the sense of adopting specific formal-stylistic elements or determining poetic orientations, cannot be recognised." ${ }^{1}$ Indeed, the construction of this segment of Croatian art from the beginning of the 2oth century, as a compact poetic whole, is based on weak foundations, which is why it would be more valid to consider the maturation and development of each of the four members of the Munich circle separately.

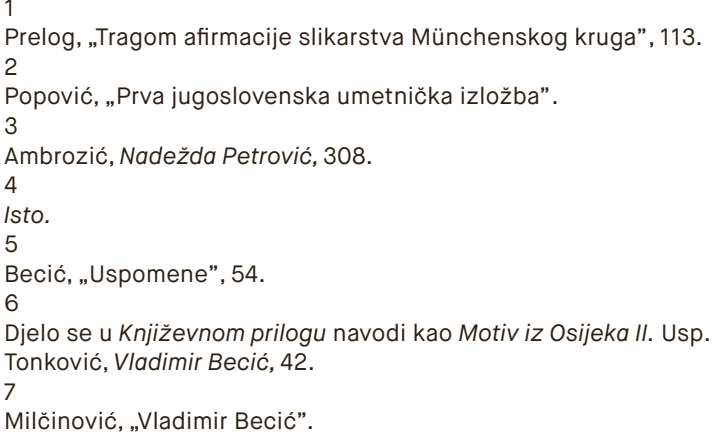


izložba je bila odskočnom daskom potpuno anonimnomu gimnazijalcu i njegovo prvo pojavljivanje u javnosti kao slikara. Nadežda Petrović tek tada, u Parizu, ulazi u Becićev život, a nekoliko će mu godina poslije riješiti važne egzistencijalne, pa i umjetničke probleme. Iz toga vremena potječe i vrlo dobar Becićev portret koji je ta slikarica učinila, a „česti gosti njenog ateljea bili su i Vladimir Becić (...), Miroslav Kraljević -kome je pozirala-i Ljubo Babić, koji je pamti iz pariskih dana kao ,žovijalnog čoveka punog veselosti i nestašluka'”. ${ }^{3}$ Nadalje, za „Becića piše Nadežda Meštroviću da je ,solidan i od prilične vrednosti sem toga pošten kao čovek i drug'”. 4

U jesen 1910. Becić napušta Pariz i tada počinju ozbiljni, štoviše, odlučujući događaji koji će mu, slobodno se može reći, odrediti život. Odlazi u Osijek gdje mu žive roditelji, a upravo su u tome gradu i njegovi slikarski počeci. Živi u Strossmayerovoj ulici, u gradskoj kući, a otvorio je atelijer u fotografskoj radnji Schrecker u Kolodvorskoj ulici. Taj je boravak smatrao privremenim. „Tražim od vlade u Zagrebu”, sjećao se kasnije, „mjesto nastavnika crtanja na gimnaziji u Bjelovaru, Karlovcu, gdjegod u provinciji. Odbijaju me, navodno zbog veleizdaje koju sam počinio time što sam izložio u paviljonu kraljevine Srbije sa Meštrovićem (Rim, god. 1911.)." 5 Koliko god taj boravak u Osijeku djelovao razočaravajuće, nastali su tada neki iznimno važni radovi. Naslikao je nekoliko portreta lokalnih uglednika, što govori o njegovoj društvenoj afirmaciji. Sve su to reprezentativna djela rađena vješto i sigurno u dobroj realističkoj maniri, ali ono što iskače iz svega što je tada nastalo niz je pejzaža kao što su Klasija, Jablani (Klasija), zatim Autoportret te mrtva priroda naslovljena Lubenice, a sve je iz 1911. godine. Slikajući Klasije, lijepi park smješten zapadno od Tvrđe prema Gornjemu gradu, Becić izlazi, slika na otvorenome s jakim svjetlosnim kontrastima koji se razlijevaju po krošnjama drveća i travnjaku. Drugoj verziji Klasija, poznatoj još i pod naslovom Jablanovi, „nedostaje dobar dio desne strane, upravo onaj ponajviše becićevski, s masama vegetacije u pozadini”, ističe Zdenko Tonković i poziva se na reprodukciju u Književnom prilogu Kluba hrvatskih književnika u Osijeku. ${ }^{6}$ Andrija Milčinović piše godine 1912. o novim Becićevim afinitetima: „U Parizu je Becić studirajući Maneta našao novog ljubimca, Paula Cézanne-a. Do kraja zanimljivi Cézanne brzo je istisnuo sve druge Becićeve ideale i danas, gdje se Becić već godinama vratio u Osijek, u kojem marljivo radi, jednako mu je na pameti Cézanne i umjetnost, što joj je taj čudnovati prorok prokrčio putove u velikom svijetu." 7

Prelog, “Tragom afirmacije slikarstva Münchenskog kruga,” IIз.

2

Popović, "Prva jugoslovenska umetnička izložba."

3

Ambrozić, Nadežda Petrović, 308 .

4

Ibid.
In the spring of 1909, Becic finished his studies at the Academy and set out for Paris where, a year earlier and at only twenty-three years of age, Josip Račić ended his life. Becić enrolled at the Académie de la Grande Chaumière, and that same year sent one watercolour to the Salon d'Automne, where it was accepted. His curiosity was great, his energy too. That same year also saw, among other things, the creation of a few of his great paintings, such as the Self-portrait with a bowler (1909) and Still life (I909). Becić had painted several self-portraits before this one, but this was his first mature work in this genre. Here one can also recognise reduction, the limiting of colour on the variation between brown and ochre tones with black accents. The expression of the face is calm, the gaze focused on the observer, and a flickering smile is barely visible under the dainty moustache and the shapely lips. Only Kraljević, but three years later and also in Paris, painted self-portraits of such painterly conviction.

Like many others in Paris, Becić visited the atelier of Ivan Meštrović, which was an important meeting point for the generation of artists who lived there and, primarily, a place for making connections and forging important strategic goals. One of the visiting artists was the Serbian painter Nadežda Petrović, who had a very important role in the organisation of the First Yugoslav Art Exhibition, which also featured a very young Vladimir Becić. This was a big manifestation that marked the hundredth anniversary of the First Serbian Uprising and the coronation of king Petar I. Karađorđević; among the 458 exhibits from ninety six artists, the work of an eighteen-yearold was also noticed by the critics. ${ }^{2}$ Moreover, the exhibition served as a springboard for the totally anonymous high-school student and was his first public appearance as a painter. It was only then, in Paris, that Nadežda Petrović entered Becić's life, while a few years later she would solve some important existential, as well as artistic problems. That was also when she painted a very good portrait of Becić, and "frequent guests of her atelier were also Vladimir Becić (...), Miroslav Kraljević-for whom she posed-and Ljubo Babić, who remembered her from the Paris days as a 'jovial person, full of cheerfulness and mischief," 3 Furthermore, "Nadežda wrote to Meštrović about Becić, saying that he was 'solid and quite valuable, in addition to being honest as a person and colleague." 4

Becić left Paris in the autumn of I9IO, which was when the serious, indeed deciding events began to happen that would, it is safe to say, determine the course of his life. He went to Osijek, where his parents lived and where he had had his painterly beginnings. He lived in Strossmayer Street, in a city-owned house, and opened an atelier in a photographic studio Schrecker in Kolodvorska Street. Becic thought of the stay as temporary. "I am asking the government in Zagreb," he remembered later, "the position of a drawing teacher at a general high-school in Bjelovar, Karlovac, anywhere in the province. 
Kao razlog zašto ne može dobiti namještenje u Osijeku, ali ni drugdje, pa bilo to i najbanalnije, Becić spominje veleizdaju. Riječ može djelovati preteškom, no činjenica je da je on, prihvativši poziv Ivana Meštrovića da izlaže na Svjetskoj izložbi u Rimu u Paviljonu Kraljevine Srbije, a odbijajući izlagati u nacionalnim paviljonima Mađarske ili Austrije kao zemljama kojima je Hrvatska u svim formalnim aspektima pripadala, u medijima i političkome životu bio na neki način obilježen. Svjetska izložba u Rimu održavala se od ožujka do prosinca 1911., a organizirana je u povodu pedesete obljetnice ujedinjenja Italije. Osim paviljona međunarodne izložbe likovnih umjetnosti, dvanaest je zemalja imalo svoje nacionalne paviljone, a među njima i Srbija. Organizacija sudjelovanja te zemlje počela je 1909., no Ivan Meštrović obratio se odboru sa željom da on i niz hrvatskih umjetnika izlažu u srbijanskome paviljonu. lako je planirani prostor bio malen, tek 75 četvornih metara, Meštrović je zahtijevao 1200 metara. Nakon mnogo natezanja Meštrovićev je prijedlog prihvaćen, a vlasti Srbije procijenile su kako bi time skrenule pozornost na sebe. lako je to negirao, iz dokumenata se vidi kako je sam Meštrović oko te izložbe bio dobro plaćen, a u stavkama troškovnika ne spominje se honorar nijednoga od ostalih hrvatskih izlagača. ${ }^{8} \mathrm{Na}$ izložbi su najviše bili zastupljeni članovi Društva hrvatskih umjetnika Medulić s Meštrovićem na čelu, a to su Toma Rosandić, Ljubo Babić, Tomislav Krizman, Mirko Rački, Vladimir Becić, Zoe Borelli, Ante Katunarić, Jozo Kljaković, Josip Lalić, Miho Marinković, Virgil Meneghello Dinčić i Ruža Meštrović, a od članova koji su tada živjeli u Beogradu Marko Murat, Nadežda Petrović i Paško Vučetić. Kao glavni razlog odbijanja izlaganja u paviljonima Mađarske ili Austrije umjetnici su naveli zabranu isticanja svoje narodnosti. Morali su se izjasniti Mađarima ili Austrijancima. Nakon niza pritisaka, za sve njih u katalogu izložbe u Paviljonu Kraljevine Srbije u konačnici je navedeno da je riječ o srpskoj umjetnosti i srpskim umjetnicima koji prikazuju povijesna zbivanja svojega naroda od Dušanova carstva do Kosova i ratovanja pod Turcima. Manipulacijama nacionalnom pripadnošću pridonio je svojim izjavama i sam Meštrović, zatim Ivo Vojnović u svojem (nepotpisanom) predgovoru u katalogu, što je izazvalo osudu i polemike, čak i onih koji su u početku pozdravili izlaganje hrvatskih umjetnika, kao što su Fran Supilo, A. G. Matoš i nekolicina drugih. Srbijanski je paviljon imao izvanrednoga odjeka, Meštrović je dobio nagradu za kiparstvo te prodao nekoliko svojih djela u ugledne zbirke, no od postava izložbe do plakata sve je podredio sebi pa se stječe dojam da su ostali umjetnici samo statirali. Kritičar Dimitrije Mitrinović piše opširne prikaze u više novina. „Prema većini je umjetnika kritičan i uočava njihove nedostatke, ali zabilježio je darovitost mladog Becića." ${ }^{9}$ Sandi Bulimbašić precizira Becićev udio u izložbi i ističe: „Treba napomenuti kako je u katalogu izložbe navedeno da je Becić izložio dva djela koja prema nazivu pripadaju Ciklusu Kraljevića MarkaPles vile u planini, Marko Kraljević i Relja Krilatica (kat. br.68a, $68 b)$-što nije točno i nitko od kritičara ne spominje ta njegova djela. Mitrinović opisuje dva Becićeva portreta rađena povlačenjem kista u širokim plohama, pastozno i u jakom koloritu." 10
They refuse, allegedly because of the high treason I committed by exhibiting in the Kingdom of Serbia's pavilion together with Meštrović (Rome, I9II)." ${ }^{5}$ As much as his stay in Osijek seemed disappointing, it resulted in some extremely important artworks. He painted several portraits of local dignitaries, which speaks to his social affirmation. Those were all representative artworks painted deftly and assuredly in a good realist manner, but what stands out from everything created at the time is a series of landscapes such as Klasija, Poplars (Klasija), then Self-portrait, and a still life entitled Watermelons, all from I9II. When painting Klasija, which is a nice park west from Tvrđa fortress, towards the Upper Town, Becić leaves the house, paints out in the open, with strong light contrasts that spill across tree tops and grass. The second version of Klasija, better known as Jablanovi, "is missing a good part from the right-hand side, precisely the part that is most essentially Becić, with a mass of vegetation in the background," says Zdenko Tonković and refers to the reproduction from the Književni prilog newspaper. ${ }^{6}$ In I9I2, Andrija Milčinović wrote about Becić's new affinities: "When studying Manet in Paris, Becić discovered a new favourite, Paul Cézanne. The always interesting Cézanne quickly pushed out all other Becić's ideals and today, after Becić has been back in Osijek for years and working diligently, he is still thinking about Cézanne and the art which that peculiar prophet pioneered in the big world."7

\section{8}

Sve povezano sa Svjetskom izložbom u Rimu 1911. i situacijom oko Meštrovića i sudjelovanja hrvatskih umjetnika citirano je, ako nije posebno navedeno, iz monografije Sandi Bulimbašić, kojoj dugujem i mnoga druga objašnjenja. Bulimbašić, Društvo hrvatskih umjetnika "Medulić" (1908.-1919.), 231-259. Isto, 251.

\section{0}

Posrijedi je Mitrinovićev tekst u Srpskom književnom glasniku (sv. 11, 1911., 888). Usp. isto.

11

Posrijedi je Lazarevićev tekst „Četvrta jugoslovenska izložba” u časopisu Reč (Beograd, 18.6.1912.). Usp. Tonković, Vladimir Becić, 43-46.

12

Posrijedi je oglas objavljen u listu Narodna obrana (Osijek, 7.10.1912.).

Usp. isto, 46-47.

13

Pismo Vladimira Becića Ivanu Meštroviću (Osijek, 17.11.1912.)

vlasništvo je nasljednika Ivana Meštrovića, Mate Meštrovića, a čuva se u Atelijeru Meštrović u Zagrebu. AAM-Pup, oznaka 105A5. 
Prema tome, to što Vladimir Becić navodi mnogo godina poslije kao glavni razlog zašto mu vlasti odbijaju molbe za zaposlenje kada im se javlja iz Osijeka nedvojbeno ima korijena i u odjecima izložbe u Rimu koju je najvećim dijelom organizirao Ivan Meštrović, u svrhu prvenstveno vlastite afirmacije i afirmacije Kraljevine Srbije, koja je njegov angažman obilato nagradila. Sljedeće, 1912. godine Becić izlaže na Četvrtoj jugoslavenskoj umjetničkoj izložbi u Beogradu sa skupinom s kojom je godinu prije izlagao u Rimu, dakle članovima Medulića. Izlaže sedam ulja, među kojima je i Portret slikara Kraljevića, Autoportret, Klasija II (Jablanovi) i kritika ga zapaža i pohvalno govori o tim djelima. B. Lazarević tako piše: „G. Becić radi pomoću ,ploha’, pomoću površina i, sa njima, daje formu, i liniju, i karakteristiku. Njegov potez je izvanredno energičan i jak, elementaran i pun temperamenta. (...) On je, uopšte, jedan vrlo smeo slikar, umetnik Maneovih revizionista... Jedan od najinteresantnijih slikara iz ,Medulića' to je bez sumnje." 11

Boravak Vladimira Becića u Osijeku se otegnuo, a neizvjesnost je bivala sve očitijom. Kada se gradilo kino Urania, bilo je predviđeno da će se u potkrovlju slikaru urediti atelijer, a on u njemu otvoriti slikarsku školu, za koju je dao i oglas. ${ }^{12}$ Međutim, iako je kino sagrađeno, Becić u njemu nije dobio atelijer. U kasnu jesen 1912. javlja se Meštroviću za pomoć, prije savjet, kako riješiti svoju situaciju te spominje i mogućnost odlaska u Beograd kamo ga je još tijekom boravka u Parizu pozvala Nadežda Petrović. ${ }^{13}$ Nadalje, Becić i Nadežda izlagali su zajedno na nekoliko važnih izložaba, kao na Prvoj jugoslovenskoj umetničkoj izložbi 1904. na kojoj je Becić izlagao i bio zapažen. Upoznali su se i družili tijekom zajedničkoga boravka u Parizu kada ga je i portretirala 1910., a sljedeće godine zajedno izlažu na Svjetskoj izložbi u Rimu u Paviljonu Kraljevine Srbije, i to u sekciji Medulić.

5

Becić, "Uspomene," 54 .

6

The Književni prilog lists the artwork as Motiffrom Osijek II. Cf. Tonković, Vladimir Becić, $4^{2}$.

7

Milčinović, "Vladimir Becić."

8

Everything related to the I9II World Fair in Rome and the situation around Meštrović and the participation of Croatian artists, unless otherwise stated, was quoted from the monograph by Sandi Bulimbašić, to whom I also owe many other explanations. Bulimbašić, Društvo hrvatskih umjetnika "Medulić"(I908.-I9I9.), 23I-259.

9

Ibid., 25I.
As the reason why he could not get a position in Osijek or anywhere else, even the most banal one, Becić mentions high treason. This word might seem too severe, but the fact is that, by accepting the invitation from Ivan Meštrovic to exhibit in the world's fair in Rome in the Pavilion of the Kingdom of Serbia, and refusing to take part in the national pavilions of Hungary or Austria as the countries to which Croatia belonged in all its formal aspects, he was to some extent stigmatised in the media and the political life. The International Exhibition of Art in Rome took place between March and December I9II, on the occasion of the 5oth anniversary of the unification of Italy. In addition to the International Exhibition of Art pavilion, twelve countries had their national pavilions, including Serbia. The organisations for the country's participation began in I909, but then Ivan Meštrović contacted the board with the plan that he and a number of other Croatian artists exhibit in the Serbian pavilion. Even though the planned space was small, only 75 square meters, Meštrović insisted on I200 meters. After a lot of wrangling, Meštrović's suggestion was accepted because the Serbian government decided that this would bring them attention. Although he denied it, the documents show that Meštrović was well-compensated for his efforts regarding the exhibition, but no other Croatian artist was mentioned as a recipient in the list of expenses. ${ }^{8}$ The most represented in the exhibition were members of the Association of Croatian Artists "Medulić," headed by Meštrović, including Toma Rosandić, Ljubo Babić, Tomislav Krizman, Mirko Rački, Vladimir Becić, Zoe Borelli, Ante Katunarić, Jozo Kljaković, Josip Lalić, Miho Marinković, Virgil Meneghello Dinčić and Ruža Meštrović, as well as some members who lived in Belgrade at the time-Marko Murat, Nadežda Petrović and Paško Vučetić. As the main reason for refusing to exhibit in the pavilions of Hungary or Austria, the artists cited the ban on emphasising their nationality: they had to identify as Hungarians or Austrians. After a series of pressures, the catalogue of the Kingdom of Serbia's pavilion finally described all of them as belonging to Serbian art and Serbian artists who were depicting historical events of their people, from Dušan's empire to Kosovo and the fight against the Ottoman Empire. The manipulation with national identities was exacerbated by statements from Meštrović himself, as well as by Ivo Vojnovic in his (unsigned) foreword of the catalogue, which were met with condemnation and polemics, even from those who initially welcomed the participation of Croatian artist, such as Fran Supilo, A. G. Matoš and several others. The Serbian pavilion was met with an extraordinary reception, and Meštrović received an award for sculpture and sold several pieces to distinguished collections; however, since he was the focus of everything from the exhibition line-up to the posters, it created an impression that the other artists were merely extras. The critic Dimitrije Mitrinović wrote lengthy reviews in multiple newspapers. "He was critical towards most artists and listed their disadvantages, but he noticed the talent of the young Becić." 9 Sandi Bulimbašić specified Becić’s contribution to the exhibition and said: "It should be 
Konačno, 1912. ponovno skupa izlažu na Četvrtoj jugoslovenskoj izložbi u Beogradu. I zaista, 17. srpnja 1913. Becić napušta Osijek i odlazi u Beograd, o čemu pišu i lokalne novine. ${ }^{14}$ Taj je odlazak definitivan, jer se više neće ovamo vraćati, a boravak u novoj sredini potpuno će usmjeriti njegov život, pa i djelo, u drugome smjeru. Od tamošnje Akademije dobiva narudžbe i izvodi deset ilustracija narodnih pjesama, dok će niz uglednih srpskih, hrvatskih i slovenskih umjetnika također raditi na ovome. Ideja da narodne pjesme ilustriraju umjetnici triju sredina nije slučajna i treba je vidjeti u duhu Jugoslovenskih izložaba koje se organiziraju od 1904. te osobito duha koji je vladao na Svjetskoj izložbi u Rimu i u Paviljonu Kraljevine Srbije s Kraljevićem Markom i Kosovskim mitom kao središnjim točkama mita koji se iz srpske povijesti želio na trijumfalan način vratiti osnažen aktualnijim političkim programom. Među slikarima koji su pozvani da rade na tome projektu bili su Paja Jovanović, Uroš Predić, Branko Popović i Dragomir Glišić od Srba, Josip Lalić, Ljubo Babić i Vladimir Becić od Hrvata te Saša Šantel i Hinko Smrekar od Slovenaca, a knjiga je izdana tek 1922. u potpuno novoj političkoj konstelaciji.

Već 1. rujna 1913. Becić dobiva profesorsko mjesto na Umetničko-zanatskoj školi u Beogradu, gdje predaje akvarel. ${ }^{15}$ Ostat će ovdje kratko vrijeme, samo do 26. studenoga, jer je Odlukom Ministarstva prosvete i crkvenih poslova postavljen za „privremenog učitelja veština” na školi u Bitolju, gradu u Makedoniji koji je odnedavno postao dijelom Srbije. ${ }^{16} \mathrm{U}$ svojim sjećanjima o tome piše: „Bježim u Srbiju 1913. god. što više u Južnu Srbiju, Bitolj kao nastavnik ,veština' i služim ,kao primjer (izjava Ljube Jovanovića Patka, ministra prosvjete) činovničkog patriotizma'." ${ }^{17} \mathrm{U}$ Bitolju je uredio atelijer u carinarnici u kojoj mu je neki Kljajić dao prostor da smjesti svoju sestru Meri te zaručnicu Ljubu Jokanović, magistru farmacije koju je upoznao u Beogradu neposredno pred odlazak u Bitolj i koja mu se pridružila. Postoji više fotografija Becićeva atelijera u Bitolju i jasno se prepoznaju i slike koje je ondje radio, ali nisu sačuvane. To su portreti mahom nepoznatih ljudi, ali i portreti Ljube Jokanović u jahačkoj uniformi i s konjima. U slikarovoj arhivi sačuvane su i fotografije na kojima su Ljuba i Becićeva sestra Meri na konju, međutim, njega također zanima okolina Bitolja, divlja priroda. U pismu od 19. prosinca 1913. tako piše: „Za čovjeka koji iskreno umjetnički osjeća za prirodu i primitivni rasni život jednog praprirodnog naroda, nema ljepšega milieua za rad, za skoncentrisanje svih svojih snaga." ${ }^{18}$ Nakon svih drugih mjesta u kojima je Becić boravio, od Münchena, Pariza, Osijeka i Beograda, Bitolj je zaista bio potpuno drugačiji. Međutim, taj je grad bio drugi po veličini u Makedoniji i imao je svojim mahom geografsko-strateškim potencijalima iznimnu važnost kako prije tako i poslije balkanskih ratova, kada je pripao Srbiji. Atelijer u kojemu se Becić smjestio bio je na kraju grada i na putu prema arheološkome nalazištu Heraklea. ${ }^{19}$ Jedini relevantni tragovi o slikarovome stvaralaštvu iz tih prvih mjeseci u Bitolju sačuvani su na fotografijama, a osim Becićevih slika koje na njima vidimo, važan je i drugi inventar, pa tako i reprodukcije Velázquezovih djela, namještaj, dekoracije na zidovima te odjeća protagonista koji su prikazani. noted that the exhibition catalogue lists two artworks by Becić which are, according to the titles, part of the Dance of fairies in the mountain, Marko Kraljevic and Relja Krilatica (cat. no. 68a, 68b) - which is not true, and there is no mention of those paintings by any of the critics. Mitrinovic describes two of Becićs portraits painted by dragging the brush in broad strokes, in the impasto technique and strong colours." 10

Therefore, the reason Vladimir Becić gives for the government's refusal of his request for a position when he came to Osijek, undoubtedly has its roots in the repercussions of the exhibition in Rome, which was largely organised by Ivan Meštrović for the purpose of his own affirmation and the affirmation of the Kingdom of Serbia, which handsomely rewarded his efforts. The following year (I9I2), Becić was part of the Fourth Yugoslav Art Exhibition in Belgrade with the same group that he exhibited the year before in Rome, meaning members of the Medulić group. He showed seven oil paintings, including the Portrait of the painter Kraljević, Self-portrait, Klasija II (Poplars), and was well-received by the critics who spoke favourably of his art. Thus B. Lazarević wrote: "Mr. Becić works with 'planes', with surfaces, which he uses to give form, and line, and characteristics. His stroke is extraordinarily energetic and strong, elementary and full of temperament. (...) He is, in general, a very bold painter, artist of Manet's revisionists... One of the most interesting painters from the 'Medulic', that is for sure." 11
„Vladimir Becić, hrvatski slikar i umjetnik, otputovao je jučer u večer, na poziv beogradske Kr. srpske akademije znanosti u Srbiju, da izradi nekoje umjetnine, ilustracije srpskim narodnim pjesmama. Razumije se, da će umjetnik upotrijebiti priliku da se pozabavi i drugima u taj čas za slikara toli zahvalnim motivima. Sretno pošao i sretno se vratio!”-„Vladimir Becić" (Narodna obrana).

Umetničko-zanatska škola Beograd, Izveštaj za školsku godinu 1913-1914, 5

16

Srpska kraljevska gimnazija u Bitolju, Izveštaj za školsku godinu 19131914., 12, 16-17.

17

Becić, „Uspomene”, 54.

18

Peić, „Vladimir Becić”, 86.

19

Na podacima o Becićevu boravku u Bitolju, ali i Solunu te njegovu ratnome razdoblju zahvaljujem Borisu Nonevskom, koji mi je ustupio rukopis svoje neobjavljene knjige. Nonevski, Makedonskata faza vo tvoreštvoto na Vladimir Becić, 56 (citirana mjesta odgovaraju paginaciji rukopisa). 


\section{RATNI SLIKAR \\ SRPSKE VOJSKE I REPORTER MAGAZINA \\ L'ILLUSTRATION}

Kada je u ljeto 1914. izbio Prvi svjetski rat, Vladimir Becić kao dobrovoljac se javio u srpsku vojsku i tu će ostati do kraja rata te proći najteže okršaje i bojišnice. U travnju 1915. Becić je organizirao izložbu svojih radova u Bitolju.

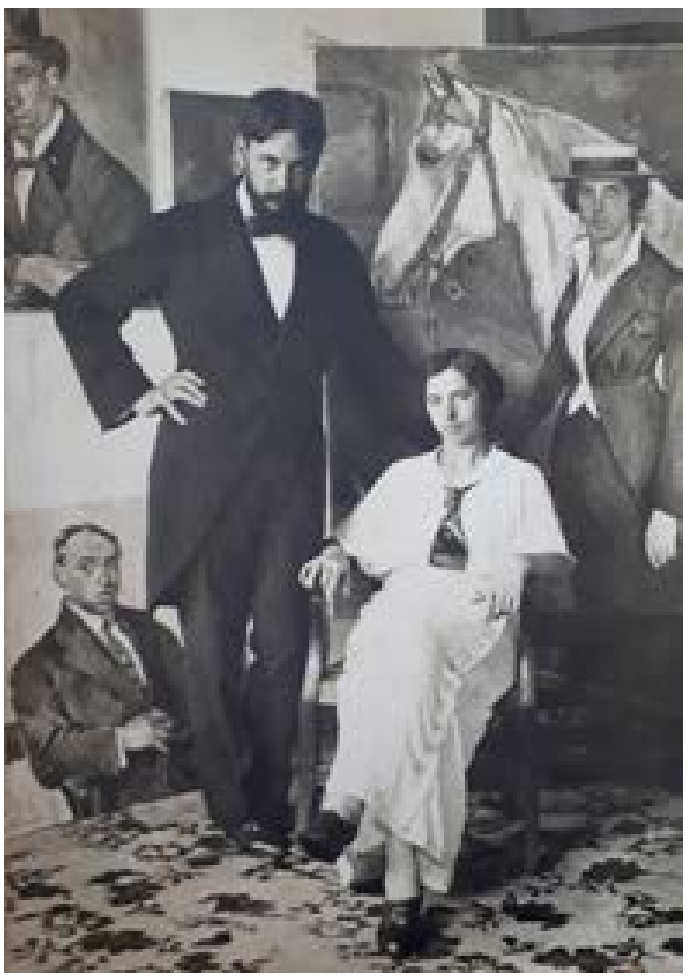

Vladimir Becić i Ljuba Jokanović u atelijeru u Bitolju 1915. Vlasništvo obitelji. Presnimka: G. Vranić / Vladimir Becić and Ljuba Jokanović in the atelier in Bitolj, I9I5. Owned by the family. Repro photo: G.Vranić $\uparrow$

10

Ibid., 25I.

11

This is Mitrinović's text in the Srpski književni glasnik (vol. II, I9II, 888.). Cf. ibid.

12

An advert published in the Narodna obrana newspaper (Osijek, October 7 , I9I2). Cf. ibid., 46-47. 13

Letter from Vladimir Becić to Ivan Meštrović (Osijek, November I7, I9I2), owned by Ivan Meštrović's heir, Mate Meštrović, and kept in the Meštrović Atelier in Zagreb. AAM-Pup, designation I05 A5. 14

"Vladimir Becić, Croatian painter and artist, left yesterday evening for Serbia, on the invitation of the Belgrade Royal Academy of Science, to make some artworks, illustrations for Serbian folk songs. Understandably, the artist will use this opportunity to work on some others, for him interesting motifs. Good luck and return back safely!"-"Vladimir Becié" (Narodna obrana).

15

Arts and Crafts School Belgrade, Report for the academic year I9I3-I9I4, 5. 16

Royal Serbian High School in Bitolj, Report for the academic year I9I3-I9I4, I2, I6-I7. 17

Becić, “Uspomene," 54 .
Vladimir Becić's stay in Osijek dragged on, and the uncertainty was becoming more pronounced. When the cinema Urania was being built, the plan was to turn the attic into his atelier, where he would open a painting school for which he already published an advertisement. ${ }^{12}$ However, even though the cinema was built, Becić did not get an atelier. In the late fall of I9I2, he wrote to Meštrović to ask for help, or rather an advice on how to deal with the situation. In the letter, he mentioned the possibility of moving to Belgrade, where he had been invited by Nadežda Petrović while they were both in Paris. ${ }^{13}$ Also, Becić and Nadežda both participated in several important exhibitions, including the First Yugoslav Art Exhibition in 1904, where Becić's work was noted. They had met and socialised during their shared sojourn in Paris, when she painted his portrait in I9Io, and the following year they exhibited together at the world fair in Rome, in the pavilion of the Kingdom of Serbia, as part of the Medulić section. Finally, in I9I2, they were again both part of the Fourth Yugoslav Art Exhibition in Belgrade. And really, on the I7th July I9I3, Becić left Osijek and went to Belgrade, which was covered by the local papers. ${ }^{14}$ This departure was definitive as he never returned again, and staying in a new environment would steer his life, as well as work, in a completely different direction. He was given commissions from the Serbian Academy and delivered ten illustrations of folk songs, a task that was also shared by a number of distinguished Serbian, Croatian and Slovenian artists. The idea that artists from three nations should illustrate folk song was not accidental, and should be viewed in the spirit of the Yugoslav exhibitions that were organised from 1904 onward, and especially in the spirit that dominated the world fair in Rome and the Serbian pavilion, with Kraljević Marko and the Kosovo myth as the central points of the myth that aspired to return from the Serbian history in a triumphant way, strengthened by the contemporary political programme. Among the painters who were invited to work on the project were Paja Jovanović, Uroš Predić, Branko Popović and Dragomir Glišić from the Serbian side, Josip Lalić, Ljubo Babić and Vladimir Becić from the Croatians, and Saša Šantel and Hinko Smrekar from the Slovenian side, but the book was not published until 1922 and a completely new political constellation.

As early as Ist September I9I3, Becić got a teaching position at the Arts and Crafts School in Belgrade, where he taught watercolours. ${ }^{15} \mathrm{He}$ would stay there only for a short time, until the 26th November, because the Ministry of Education and Religious Affairs appointed him as a "temporary skills teacher" at a school in Bitolj, a city in Macedonia that had recently become part of Serbia. ${ }^{16}$ In his memoirs, he wrote about that time: "In I9I3, I am running to Serbia, and South Serbia at that, to Bitolj, as a teacher of 'skills' in order to serve as an example (statement of Ljubo Jovanović Patak, Minister of Education) of clerical patriotism." ${ }^{17}$ In Bitolj he set up an atelier in the customs house, where a man called Kljajić gave him the space to house his sister Meri and fiancée Ljuba Jokanović, master of pharmacy, whom he met in Belgrade just before leaving for Bitolj and who joined 
To je bila prva izložba koja je uopće održana na prostoru današnje Makedonije. Na njoj je izložio 31 djelo, a u nedostatku uljanih boja radio je u sepiji i akvarelu. ${ }^{20} \mathrm{O}$ toj je izložbi objavljen prikaz u lokalnim novinama iz kojega saznajemo što je bilo izloženo. ${ }^{21}$ Štoviše, iz naziva i opisa izložaka doznajemo kako je riječ o ratnim motivima, ali ne uvijek i onima s fronte pa se konstatira da je šteta što Becić nije imao prigode sve raditi u neposrednom kontaktu s teškim ratnim događajima koje prikazuje, nego se djelomice oslanjao na maštu. Međutim, opisujući sliku Jedan sprovod ističe se da je to „realna studija” ratne svakodnevice na fronti. Becić prikazuje seljačka kola koja vuku dva mršava vola, a u kolima je sanduk s tijelom mrtvoga vojnika. Na jednoj drugoj slici, U bolnici, pokraj bolničkoga kreveta sjedi bolničarka, a njoj je umjetnik dao izgled svoje zaručnice Ljube Jokanović. ${ }^{22}$ Nakon Bitolja izložba će biti organizirana i u Solunu, gdje je najavljuju u francuskim novinama koje izlaze u tome gradu. Osim najava, novine L'Indépendant donose i stručnu recenziju koju potpisuje Adolphe Beaune. Nakon što je izložba zatvorena, novine L'Opinion (18. travnja 1915.) izvještavaju da je zanimanje za izložbu Vladimira Becića bilo veliko i da se čekalo u redu kako bi se ušlo u izložbeni salon. ${ }^{23}$

Dana 19. travnja 1915. Vladimir Becić i Ljubica (Ljuba) Jokanović sklopili su brak u Bitolju. Samo dan poslije Becić se obraća ministru vojske s molbom da ga se postavi na dužnost ratnoga slikara ${ }^{24}$ u štabu 1. šumadijske divizije i na tu je dužnost imenovan 23. svibnja $1915 .^{25}$ Becićevim odlaskom u rat njegova supruga ostaje sama u Bitolju i s vlasnikom ljekarne u kojoj je radila dogovara se o raskidu ugovora te 14. studenoga 1915. i napušta posao s najboljim preporukama. ${ }^{26}$ Odlazi u Solun, dok je Becić sa srpskom vojskom od Smedereva i Kraljeva, preko Prištine i Prizrena u masovnome i dramatičnome povlačenju vojske i naroda preko Crne Gore i Albanije stigao na Jadran. Tijekom povlačenja fotografirao je događaje kojima je svjedočio pa tako nastaje jedinstvena serija dokumentarnih fotografija, ali i ilustracija koje će godinu poslije objaviti uz svoj tekst u časopisu L'Illustration. ${ }^{27}$ Osim samih događaja, prizora bitaka, zbrinjavanja ranjenika i ubijenih tijekom srpskoga povlačenja, pa i svega drugoga što se događalo na Solunskoj fronti i u samome Solunu, objavljuje i portrete istaknutih vojskovođa, od kralja Petra I. Karađorđevića i prijestolonasljednika Aleksandra, do poznatih generala kao što su vojvoda Petar Bojović, vojvoda Živojin Mišić i drugih. U kasnu jesen 1915. Becić je, preko Skadra i Medove (S. Giovanni di Medua), stigao u Rim, gdje je upoznao dopisnika francuskog ilustriranog magazina L'Illustration Roberta Vauchera. Na njegov je nagovor otputovao u Pariz i 30. prosinca 1915. postao dopisnikom tog visokotiražnog polumjesečnika. ${ }^{28}$ Za ratnog slikara vrhovna zapovjedništva srpske vojske postavljen je pak 30. travnja $1916 .{ }^{29}$ Među prvim je prilozima Vladimira Becića u magazinu L'illustration reportaža La maleureuse Serbie s brojnim ilustracijama, od kojih je osobito zanimljiva ona iznad naslova na kojoj je prikazan kralj Petar I. kako napušta Staru Srbiju na dvokolici s volovskom zapregom i na putu prema Prištini susreće njemačke zarobljenike. Taj motiv Becić će raditi u nekoliko verzija i steći će iznimnu popularnost. Ispod naslova piše kako je to him there. There are multiple photos of the Becić atelier in Bitolj, in which we can clearly recognise the paintings he worked on, but which were not preserved. Those were portraits of mainly unknown people, but also Ljuba Jokanović in a rider's uniform and with horses. The painter's archive also keeps photographs of Ljuba and Becić's sister Meri on a horse, but he was also interested in Bitolj's surroundings, the wild nature. In a letter dated the I9th December I9I3, he wrote: "For a man who has a sincere artistic feeling for nature and the primitive race life of a pre-natural people, there is no milieu more beautiful for working, for focusing all his efforts." 18 After all the other places he lived in, from Munich, Paris, Osijek and Belgrade, Bitolj really was completely different. And yet, the town was the second largest in Macedonia and had, mostly owing to its geographic-strategic potential, a great importance before as well as after the Balkan Wars, when it was ceded to Serbia. The atelier of which Becić took possession was at the edge of town, on the way towards the Heraclea archaeological site. ${ }^{19}$ The only relevant traces of the painter's creativity during those first few months in Bitolj can be found in photographs: in addition to his paintings, what is also important is the other inventory, including the reproductions of Velásquez's paintings, furniture, decorations on the walls and the clothes of the protagonists.

\section{0}

Isto, 78. 21

Posrijedi je članak „Izložba ratnih slika Vlade Becića” objavljen u listu Bitoljske novine (Bitolj, 6. i 8.4.1915.). Usp. isto, 76 i dalje. 22 Isto, 80 . 23

L'Indépendant donosi najavu 10. travnja pod naslovom „Exposition peinture-Tableaux de la guerre", da će se u nedjelju 12. travnja otvoriti izložba u Salons du Parc Tour Blanche ratnih slika Vladimira Becića. Sličnu najavu donose, također 10. travnja, i novine L'Opinion pod naslovom "Exposition artistique”. Usp. isto, 81-86.

24

Arhiv Srbije, Beograd, AC, MPs-P, 1915., f 3, r 19.

25

Arhiv Vojnoistorijskog instituta, Beograd, Popisnik 3, kutija 83, fascikl 2, broj 10/25, list 1.

26

Dokument o razrješenju Ljubice (Jokanović) Becić na mjestu magistre farmacije u ljekarni „Kod orla” i preporuci vlasnika ljekarne g. Đure Lakića nalazi se u Ženevi u privatnom arhivu dr. Vladimira Velebita, slikarova unuka i sina druge Becićeve kćeri Vere (Becić) Velebit. 27

Betzich, "Comment se battent les derniers Serbes”. 28

Fotoarhiv Vojnog muzeja, Beograd, Ratni dopisnici, br. 959, 19. 29 Arhiv Vojnoistorijskog instituta, Beograd, Popisnik 3, kutija 151, fascikl 14, broj $6 / 3$, list 1.

30

Tonković, „Vladimir Becić”, 66-74.

31

Tonković, „Slikari fotografi”, 338. 
pripovijest jednoga srpskog izbjeglice, a u donjem je dijelu Becićeva fotografija na kojoj sjedi ispred šatora. U svim se elementima želi istaknuti autentičnost iskaza, i autora teksta, i fotografije, i ilustracija koje su rađene na licu mjesta. Od prvoga broja magazina do svih sljedećih u kojima su tijekom godina objavljivani Becićevi prilozi otkrivamo potpuno novu dimenziju ovoga umjetnika. Spominjući upravo taj segment umjetnikova rada, Zdenko Tonković s pravom ističe: „Iz perspektive današnje medijske kulture, nove valorizacije i ponderiranja ilustracije i fotografije, Becićeva trogodišnja suradnja s L'Illustration u vremenu sudbonosnih događanja ima nezaobilazno značenje." ${ }^{30}$ Što se pak fotografije tiče, Marija Tonković u studiji o slikarima fotografima konstatira da među „hrvatskim likovnim umjetnicima Vladimir Becić svakako je najmarkantnije ime amaterske fotografije". ${ }^{31}$ Korijene umjetnikova zanimanja za fotografiju, štoviše, dobroga poznavanja fotografije kao samostalnoga medija, autorica pomiče u Becićeve osječke dane.

18

Peić, "Vladimir Becić," 86.

19

For the information on Becićs stay in Bitolj, but also Thessaloniki and his entire war-time activity, I thank Boris Nonevski, who provided me with the manuscript of his unpublished book. Nonevski, Makedonskata faza vo tvoreštvoto na Vladimir Becić, 56 (quoted text corresponds to the manuscript pagination).

20

Ibid., 78 .

21

This is the article "Izložba ratnih slika Vlade Becića" [Exhibition of

Vladimir Becić' War Paintings] published in the Bitoljske novine paper (Bitolj, April 6 and 8, I9I5). Cf. ibid., 76 and onwards.

22

Ibid., 80 .

23

L'Indépendant published an announcement on the Ioth April, under the title "Exposition peinture-Tableaux de la guerre," that on Sunday, i2th April, an exhibition of Vladimir Becić's war paintings will open at the Salons du Parc Tour Blanche. A similar announcement was also published on the roth April by the newspaper L'Opinion, entitled "Exposition artistique." Cf. ibid., 8I-86.

24

Archive of Serbia, Belgrade, AC, MPs-P, I9I5, f 3, r I9.

25

Archive of the Institute of Military History, Belgrade, List 3, boxa 83, folder 2, number Io/25, page I.

26

Document on the termination of contract of Ljubica (Jokanović) Becić as a master of pharmacy in the pharmacy "Kodorla," and the recommendation of the owner, Mr Đuro Lakić are kept in the private archive of dr. Vladimir Velebit in Geneva, the painter's grandson and son of second Becić' daughter Vera (Becić) Velebit. 27

Betzich, "Comment se battent les derniers Serbes."

\section{WAR PAINTER OF THE \\ SERBIAN ARMY AND CORRESPONDENT FOR THE \\ L'ILLUSTRATION MAGAZINE}

When the First World War broke out in the summer of I9I4, Vladimir Becić voluntarily joined the Serbian army, where he would remain till the end of the war and live through the toughest battles and battlefields. In April I9I5, Becić organised an exhibition of his work in Bitolj. This was the first exhibition held on the territory of today's Macedonia. It featured 3I artworks which, due to the lack of oil paint, were done in sepia and watercolours. ${ }^{20}$ The exhibition was covered in the local newspaper, which provide us information about the pieces that were shown. ${ }^{21}$ Moreover, the titles and descriptions of exhibits tell us that those were war motifs, but not always those from the frontline, which led to the conclusion that it was a shame that Becić did not have an opportunity to work in a direct contact with difficult war events he was depicting, but had to rely partly on his imagination. However, the description of the painting A funeral points out that it is a "realist study" of everyday life on the frontline. Becić painted a farm wagon pulled by two thin oxen, carrying a coffin with a dead soldier. Another painting, In a hospital, shows a nurse sitting by a hospital bed, whose appearance was modelled after the artist's fiancée Ljuba Jokanović. ${ }^{22}$ After Bitolj, the exhibition was organised in Thessaloniki, where it was announced in the town's French newspaper. In addition to the announcement, the L'Indépendant paper published an expert review signed by Adolphe Beaune. After the closing of the exhibition, the L'Opinion newspaper reported (I8th April I9I5) that the interest for the exhibition by Vladimir Becić was great and that people waited in line to enter. ${ }^{23}$

On the I9th April I9I5, Vladimir Becić and Ljubica (Ljuba) Jokanović got married in Bitolj. Only a day later, Becić wrote to the minister of the army and requested to be appointed as a war painter ${ }^{24}$ with the Command of the First Šumadija divison, which he officially became on the 23rd March $19 \mathrm{I} 5 .{ }^{25}$ When Becić left to go to war, his wife was left alone in Bitolj, and so she arranged a termination of contract with the owner of the pharmacy she had been working in, and on the I4th November I9I5 left work with the highest recommendations. ${ }^{26}$ She went to Thessaloniki, while Becić followed the Serbian army from Smederevo and Kraljevo, across Priština and Prizren in a massive and dramatic withdrawing of the army and civilians across Montenegro and Albania, and arrived at the Adriatic coast. During the withdrawal, he photographed the events he witnessed, thus creating a unique series of documentary photos, but also illustrations that he would publish a year later in the L'Illustration magazine, ${ }^{27}$ along with his texts. In addition to the events themselves, to the scenes of battles, of taking care of the wounded and killed during the Serbian withdrawal, and of everything else that happened on the Salonica front and in Thessaloniki, he also published portraits of distinguished army leaders, from the king Petar I. Karađorđević and crown prince Aleksandar, 


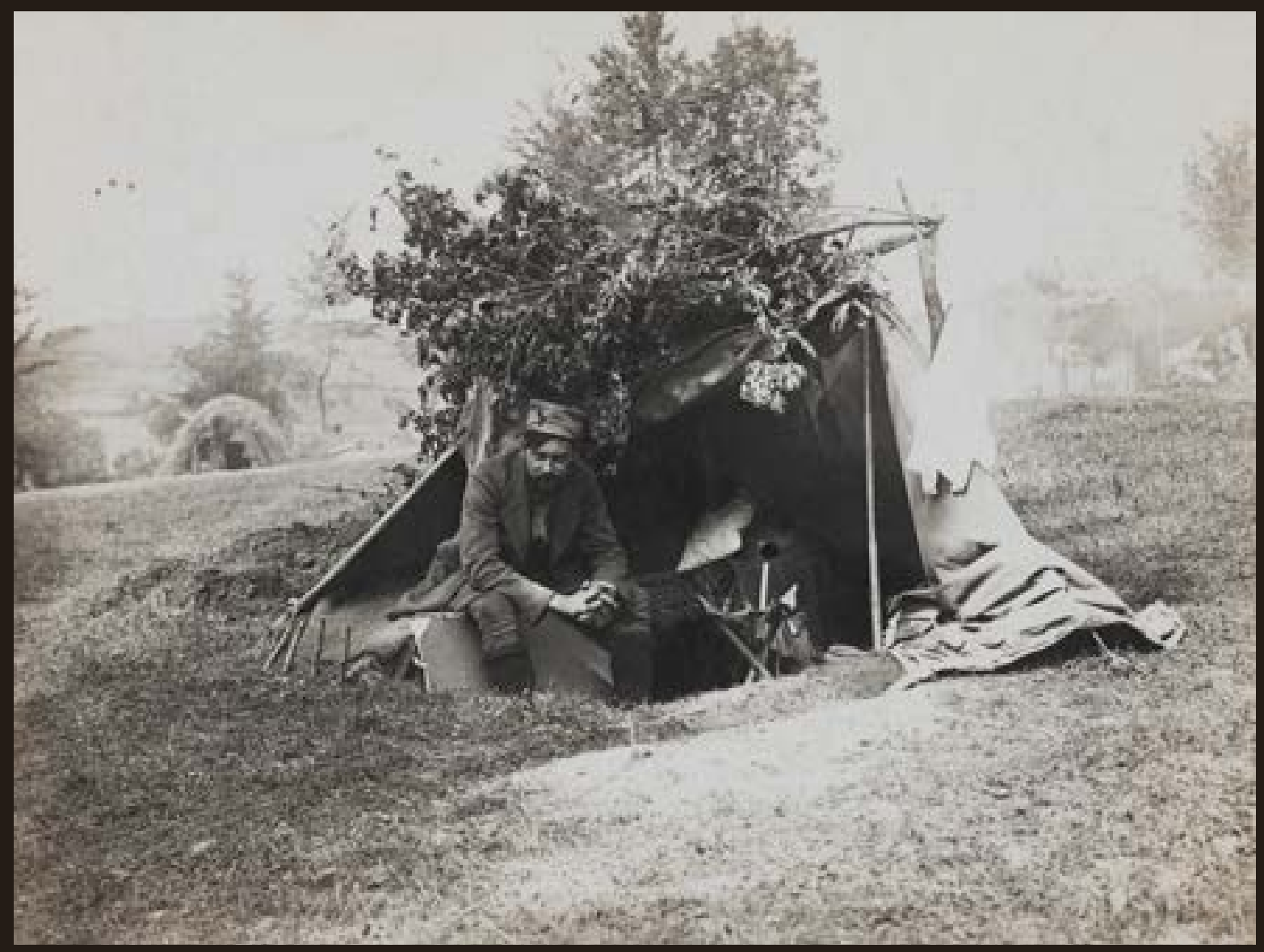

$\uparrow$

Vladimir Becić ispred svojega šatora na bojišnici negdje u Južnoj Srbiji u jesen 1915. Likovni arhiv HAZU. Presnimka: G.Vranić /

Vladimir Becić in front of his tent at the battlefront somewhere in southern Serbia, autumn of 1915. Fine Arts Archives of the Croatian Academy of Sciences and Arts. Repro photo: G. Vranić

Kralj Petar I. Karađorđević na putu u egzil. L'Illustration, 1. siječnja 1916. Likovni arhiv HAZU. Presnimka: G. Vranić / King Petar I. Karađorđević on his way to exile. L'Illustration, January I, I916. Fine Arts Archives of the Croatian Academy of Sciences and Arts. Repro photo: G. Vranić 


\section{L'ILLUSTRATION}

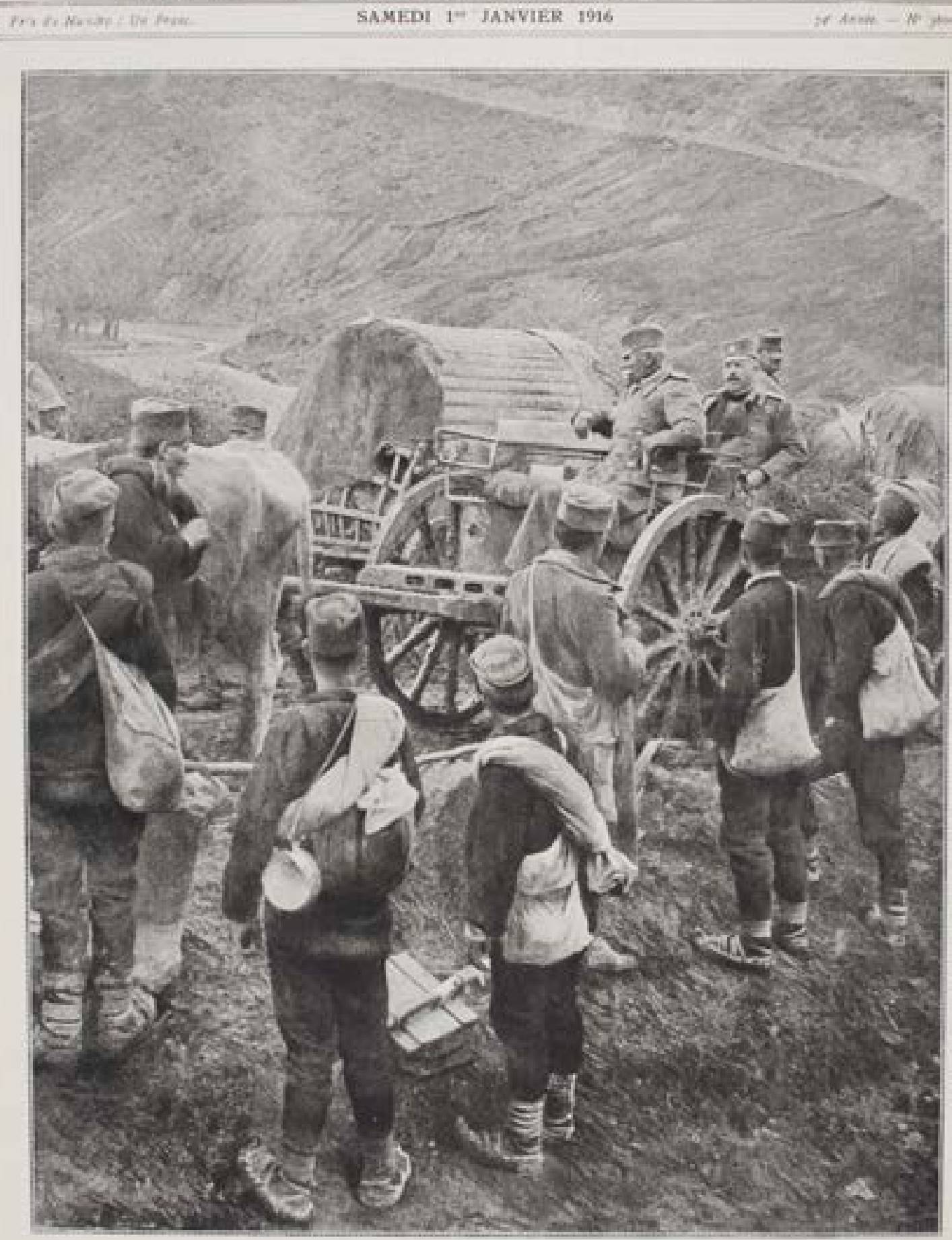

LE VIEUX ROI PIERRE DE SEREIE SUR LA ROUTE DE LKXIL 
Nakon Münchena njegov je prvi atelijer u Osijeku u fotografskoj radnji Schrecker u Kolodvorskoj ulici, a autorica se referira konkretno na promotivni članak anonimnog autora kojemu je „očito Becić držao ruku”, a u kojem se „eksplicitno spominje fotografija i sa jasnim određenjem”: „Naša publika, nažalost, naučena na kojekakve salonske portretiste Laszloa, Jovanovitya ili Madžara Benczura, zahtijeva od umjetnika da donese precizno sve ono, što i oni sami, recimo na pr. na svojoj ruci vide kao: svaku boru kože, svaku žilicu, zanokticu, itd., jednom riječju: sve ono što im jedan dobar Götzov fotografski aparat može da pruži za par filira, a što nije i ne smije da bude zadaća pravog umijeća i umjetničkog stvaranja." ${ }^{32}$ Nešto kasnije autorica ističe Becićevo odlično poznavanje primjene fotografije $u$ to vrijeme, osobito u njegovu članku „Umjetničke fotografije gosp. Luje Varnaija”. ${ }^{33}$ Sve bi to rano Becićevo zanimanje za fotografiju bilo svojevrsnim uvodom u njegov u punom smislu riječi profesionalni rad ratnoga fotoreportera. Na više od dvadeset pet objavljenih fotografija u magazinu L'Illustration, na trideset pet negativa na staklu koji se čuvaju u Vojnome muzeju u Beogradu, a dio se nalazi u arhivu umjetnikove obitelji te u građi koju je obitelj dala Likovnome arhivu Hrvatske akademije znanosti i umjetnosti, zaključak je jasan: „Becićeva suradnja sa L'Illustration jedan je od vrhunaca hrvatske reportažne fotografije: tek prelistavajući ta dva godišta i u usporedbi s drugim autorima, nedvojbena je njegova visoka razina, sa modernošću koja je izdržala provjeru vremena." 34

Od svih fotografskih priloga i ilustracija koje je Becić objavio u časopisu L'Illustration nedvojbeno su najveći efekt imali oni s prikazima kralja Petra I. Već u prvome broju objavljena je ilustracija koja prikazuje kralja u kolima s volovskom zapregom na putu prema Prištini, što će reći u progonstvo. Objavljena je također na naslovnoj stranici i fotografija s istim motivom, a naslovljena Le vieux roi Pierre de Serbie sur la route de l'exil koja je snimljena 6. studenoga 1915. u Jankovoj klisuri. Na njoj je naznačeno da je kralj na putu prema Prizrenu, a okružen je mladim novacima od 15 i 17 godina. Taj jednostavan narativ ima svoje dublje značenje: Srbiju su prisiljeni napustiti i stari kralj, i mladost te zemlje, cvijet Srbije. Ono je što ostaje pustoš, a egzil je neizvjestan. Zaista, tek će nakon Prizrena uslijediti izbjeglički pakao u planinama Crne Gore i Albanije. Becićeva fotografija u svim elementima upućuje na autentičnost: tu nema lijepo konstruirane kompozicije, prizor je uhvaćen slučajnim pogledom kako bi se naglasili efekti rasula. Međutim, Vladimir Becić će osnovni narativ mijenjati u još nekoliko verzija. Snimit će i objaviti u istome časopisu još jednu fotografiju kralja u egzilu, ali ovaj put u kolima u koja su upregnuta četiri mršava, sasvim izgladnjela vola. Ta će fotografija biti predloškom za prikaz izrađen u akvarelu (1917.) koji će u kompozicijskom pogledu smiriti te dovesti do pravilna ritma i prostorne artikulacije. Međutim, akvarel je predradnja za uljanu sliku velikoga formata, a i ona je trebala biti tek predloškom za jedno reprezentativnije djelo, za fresku. Sve se na akvarelu, a još bolje je to vidljivo na uljanoj slici, odvija u jednome izduženom kadru ispunjenom nekolicinom likova koji su pratnja kralju. To više nisu njemački zarobljenici to well-known generals like the duke Petar Bojović, duke Živojin Mišić and others. In late autumn of I9I5, Becić travelled through Skadar and Medova (S. Giovanni di Medua) to arrive in Rome, where he met the reporter for the French illustrated magazine L'Illustration Robert Vaucher. At his suggestion, Becic travelled to Paris and, on the zoth December I9I5, became a correspondent for that masscirculation semi-monthly publication. ${ }^{28}$ On the 30 th April I9I6, he was appointed as the war painter of the High Command of the Serbian army. ${ }^{29}$ Among the first contributions of Vladimir Becić to the L'illustration magazine was a report "La maleureuse Serbie" with numerous illustrations, the most interesting one being the illustration published above the title, which showed the king Petar I. leaving Stara Srbija on an oxcart and meeting some German prisoners on the way to Priština. Becić would make several version of this motif, which would become very popular. The text under the title said that it was a story of a Serbian refugee, while the lower part of the page featured a photograph of Becić sitting in front of a tent. All these elements served to emphasise the authenticity of the account, the author, the photograph, and the illustrations that were made on the spot. From that first magazine issue, to all the others that featured Becićs contributions through the years, we discover an entirely new dimension of the artist. Commenting on just this segment of the artist's work, Zdenko Tonković rightly noted: "From the perspective of today's media culture, of a new valorisation and pondering of illustration and photography, Becić's three-year cooperation with L'Illustration, at the time of fateful events, has an unavoidable significance." 30

Posrijedi je tekst objavljen u Narodnoj obrani (Osijek, 10.7.1911.). Usp. isto, 338. 33 Becić, „Die Kunstphotographien des Herrn Varnai”. 34 Tonković, „Slikari fotografi”, 349. 
ni unovačeni srpski mladići, pa ni seljaci koji prate svojega kralja. Istina, i ovdje ćemo naći seljake, krajnje desno, ali oni su dobro uhranjeni i lijepo odjeveni. Naći ćemo ranjena vojnika s povezom na glavi iza kralja, a tu su još i vojni starješine. Osim kralja koji sjedi u kolima svega je osam isključivo muških likova koji su mu pratnja ili ga možda samo pozdravljaju, kao dva seljaka s desne strane, jedan ispred, a drugi iza volova. Ovu je sliku Becić prvi put izložio krajem prosinca 1919. na svojoj prvoj poslijeratnoj izložbi u zagrebačkom Salonu Ullrich.

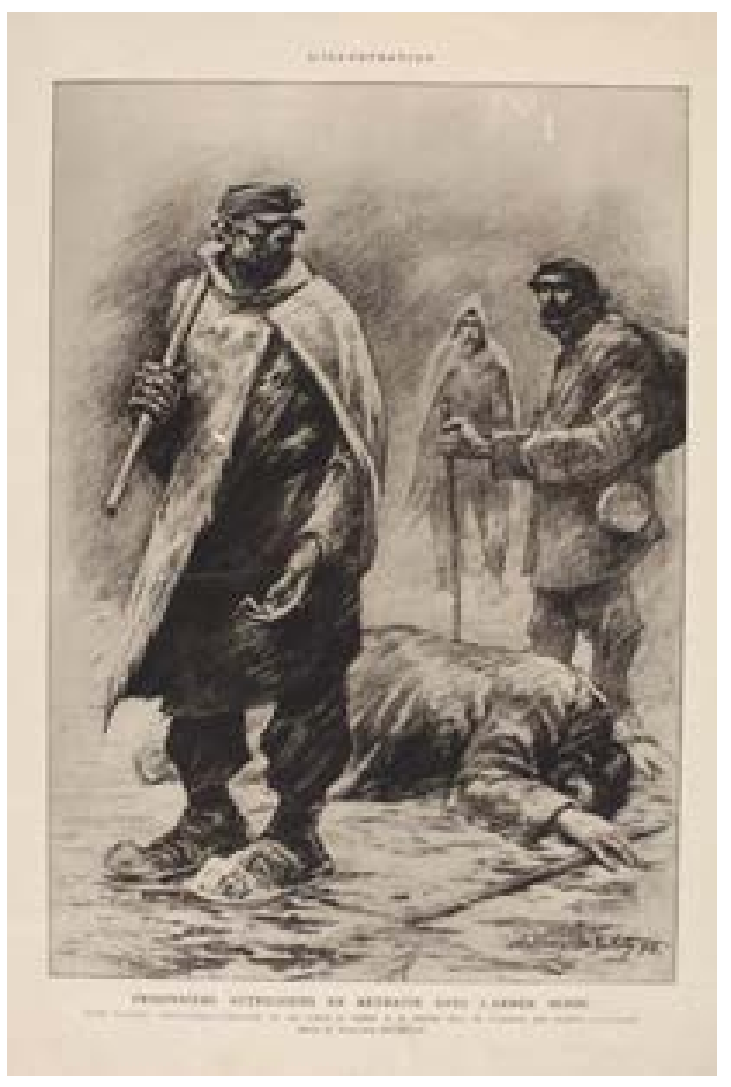

Austrijski zarobljenici pri povlačenju sa srpskom vojskom 1916. L'Illustration. Likovni arhiv HAZU. Presnimka: G. Vranić / Austrian prisoners retreating with the Serbian army in I9I6. L'Illustration. Fine Arts Archives of the Croatian Academy of Sciences and Arts. Repro photo: G. Vranić $\uparrow$

28

Photo-archive of the Military Museum, Belgrade, Ratni dopisnici, no. 959, I9.

29

Archive of the Institute of Military History, Belgrade, List 3, box I5I,

folder $\mathrm{I}_{4}$, number $6 / 3$, page $\mathrm{I}$.

30

Tonković, "Vladimir Becić," 66-74.

31

Tonković, "Slikari fotografi," 338.

32

This is a text published in Narodna obrana (Osijek, July Io, I9II). Cf. ibid., 338 33

Becić, "Die Kunstphotographien des Herrn Varnai." 34

Tonković, "Slikari fotografi,” 349.
As for the photography itself, in her study on painters-photographers, Marija Tonković stated that, among "Croatian visual artists, Vladimir Becić is definitely the grandest name of amateur photography." ${ }^{31}$ She traced the roots of the artist's interest in photography, indeed of his considerable knowledge of photography as an autonomous media, to his Osijek days. After Munich, his first atelier in Osijek was in Schrecker photo studio in Kolodvorska Street, and the author specifically refers to the promotional article by an anonymous author whose "hand Becić obviously held," which "explicitly mentions photography, and with a clear determination:" "Our public, unfortunately used to all kinds of salon portraitists like Laszlo, Jovanovity or the Hungarian Benczur, demands from artists to precisely show everything they themselves can see, for example on their hand: every wrinkle, every vein, every hangnail, etc., in a word: everything that a good Götze camera can give them for a couple of filirs, or rather what is not nor should be the task of true art and artistic creation., ${ }^{32} \mathrm{~A}$ bit later, the author noted Becićs excellent knowledge of applied photography at that time, especially as demonstrated in his article "Umjetničke fotografije gosp. Luje Varnai-ja" [Artistic photographs of Mr Lujo Varnai]. ${ }^{33}$ All this early interest in photography was a sort of an introduction to his, one mighty freely say, professional work as a war press photographer. More than twenty-five published photographs in the L'Illustration magazine, thirty-five glass negatives that are kept in the Army Museum in Belgrade, and others in the archive of the artist's family and in the materials donated by the family to the Fine Arts Archives of the Croatian Academy of Sciences and Arts, all lead to a clear conclusion: "Becić's cooperation with the L'Illustration is one of the highlights of Croatian press photography: just by browsing through these two volumes and comparing it to other authors, one cannot doubt the high level of quality of his work, with a modernity which stood the test of time." ${ }^{34}$

Of all the photographic contributions and illustrations that Becić published in the L'Illustration, the ones that undoubtedly had the biggest effect were those which showed king Petar I. The very first issue published an illustration depicting the king in an oxcart on the way to Priština, or rather to exile. The issue's cover further featured a photograph of the same motif, entitled Le vieux roi Pierre de Serbie sur la route de l'exil, taken on the 6th November 1915 in Jankova klisura. It stated that the king was on his way to Prizren, and was surrounded by young recruits between I5 and I7 years of age. This simple narrative had a deeper meaning: both the old king and the flower of the youth had been forced to leave Serbia. What remained was a wasteland, and the exile brought only uncertainty. And indeed, it was only after Prizren that the refugee hell in the mountains of Montenegro and Albania followed. Becićs photograph indicates authenticity in all its elements: there is no carefully-arranged composition, the scene was captured with an incidental gaze in order to emphasise the effects of the chaos. However, Vladimir Becić would change the basic narrative in several subsequent versions. 


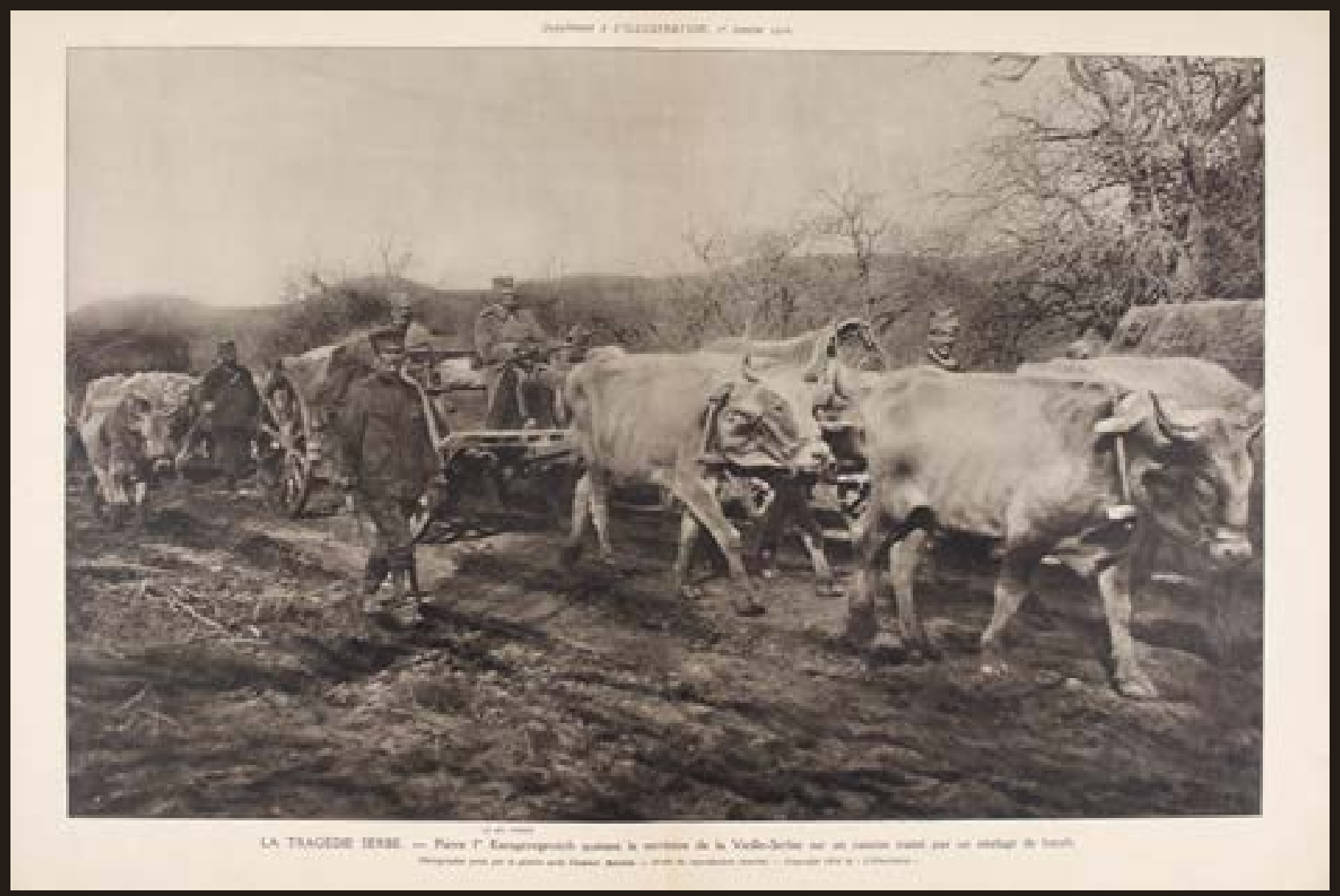

$\uparrow$

Srpska tragedija: Kralj Petar I. Karađorđević napušta teritorij stare Srbije na kolima s četiri vola. L'lllustration, 1. siječnja 1916. Likovni arhiv HAZU.

Presnimka: G. Vranić / Serbian tragedy: King Petar I. Karađorđević leaving the territory of old Serbia on a four-ox wagon. L'Illustration, January I, I9I6. Fine Arts Archives of the Croatian Academy of Sciences and Arts. Repro photo: G. Vranić

Kralj Petar I. Karađorđević susreće njemačke zarobljenike na putu za Prištinu. L'Illustration, 1. siječnja 1916. Likovni arhiv HAZU. Presnimka: G. Vranić / King Petar I. Karađorđević meets German prisoners on the way to Priština. L'Illustration, January I, I9ı. Fine Arts Archives of the Croatian Academy of Sciences and Arts. Repro photo: G. Vranić 


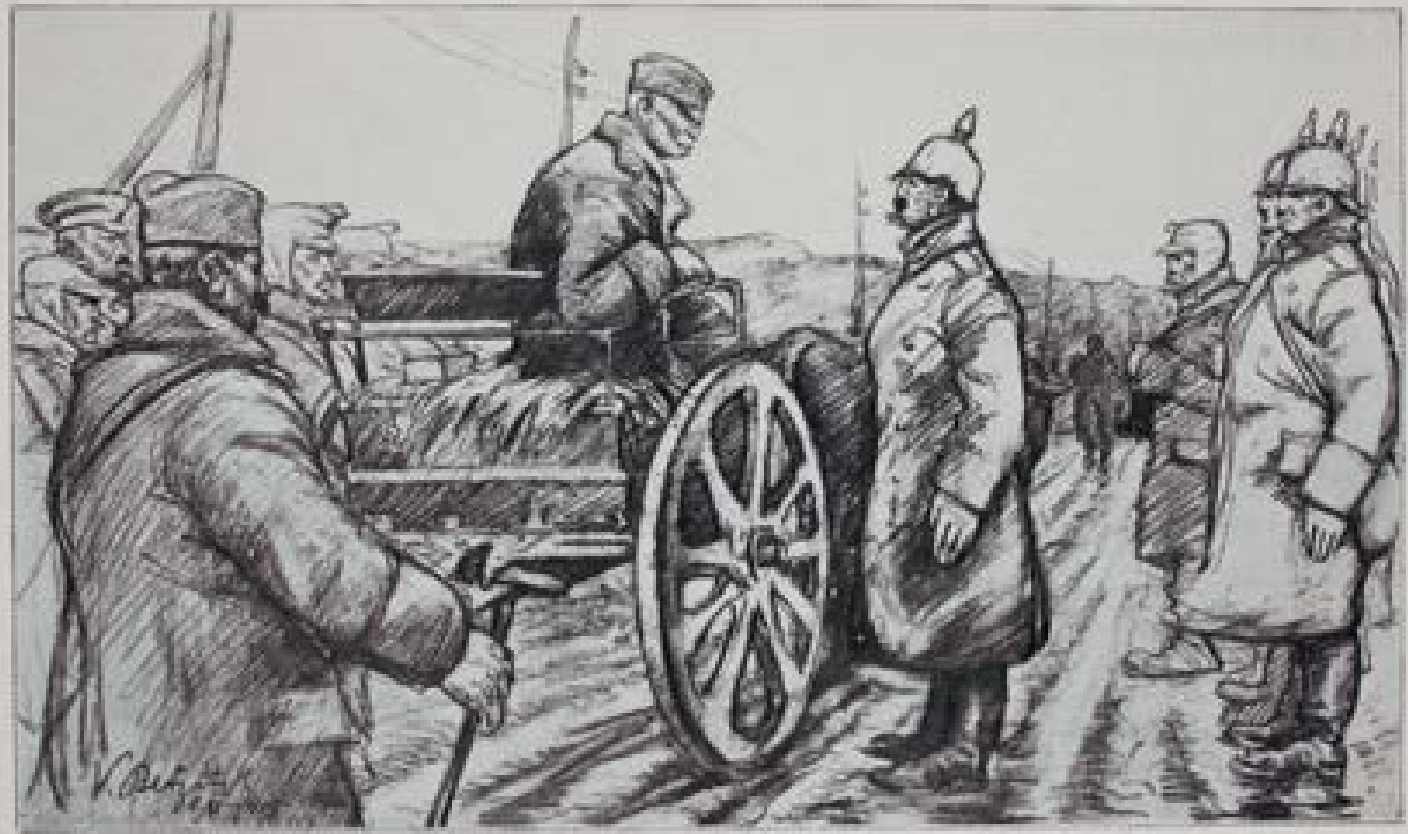




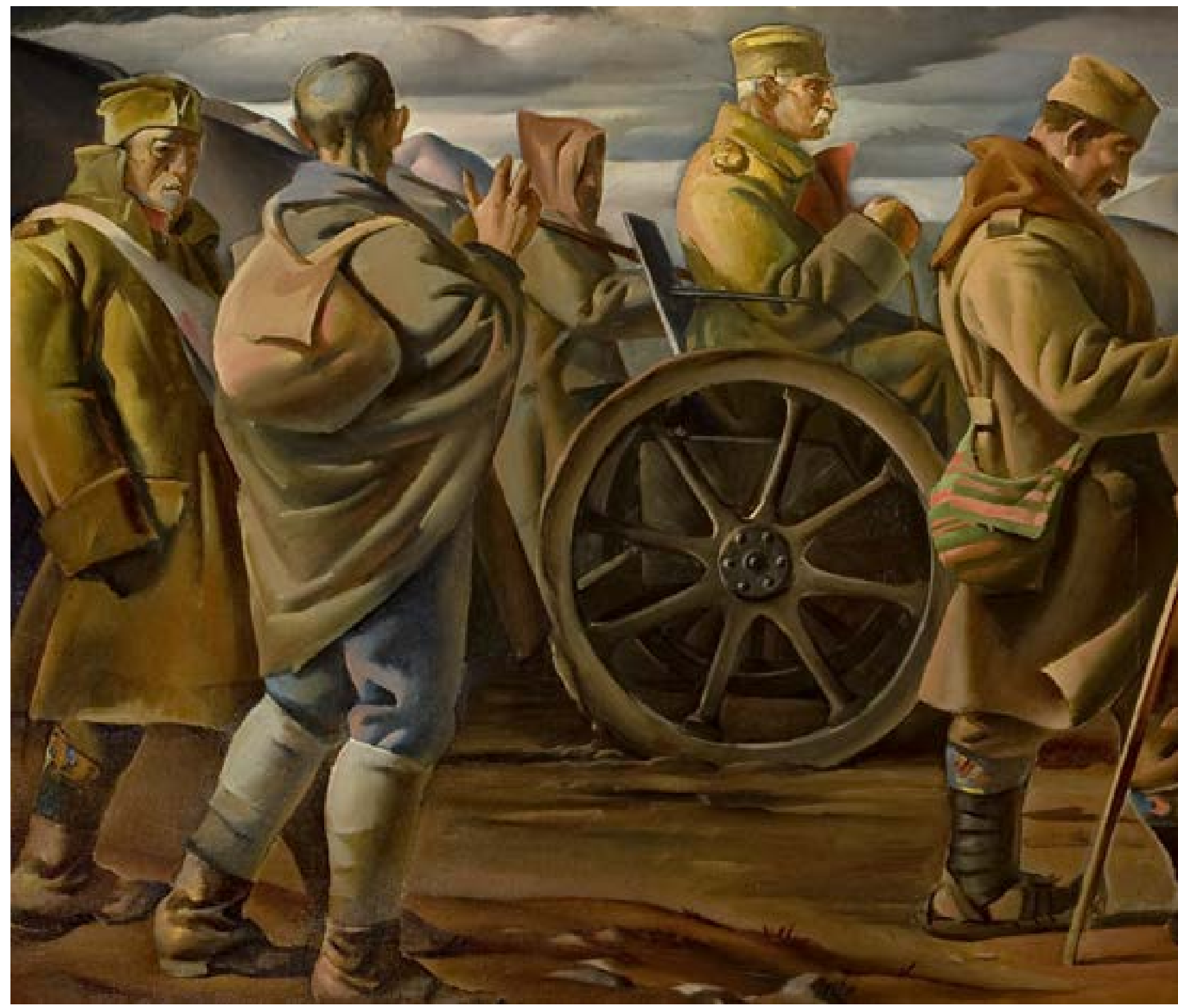


Iz vrlo uredno vođene evidencije gospodina Ullricha saznajemo kako su na izložbi prikazana 44 Becićeva djela, od crteža i litografija do uljanih slika, i da ih je 39 prodano. Prva je na popisu upravo ova slika, sada naslovljena Kraljevo povlačenje, s uvjerljivo najvišom cijenom. Procijenjena je na 25.000 kruna, dok je sljedeća, Autoportret, procijenjena i prodana za 10.000 kruna, a slijedi Mladi Englez, čija je cijena bila 6.000 kruna. Za sliku Kraljevo povlačenje navedeno je da ju je kupio g. Stanković iz Subotice, Autoportret gospođa E. Erlich itd. ${ }^{35}$ Kritika je popratila Becićevu izložbu i vrlo povoljno pisala o njoj. U jednom napisu komentira se i slika Kraljevo povlačenje: „Velika je slika studija za fresko: ,Kraljevo povlačenje'; dobro je komponovana, ali držim da će se u još koječem i promijeniti, kad bude jednom na fresko izvedena. To je prikaz kralja, koji se povlači, ne kao bjegunac, nego svjestan, da je pobjeda njegova. I tako je bilo. Slika je načinjena monumentalno, sve sporedno stupa u pozadinu ili služi samo tomu, da se glavni motiv istakne.” ${ }^{36}$

Freska nije izvedena, ali distribucija Becićeva prikaza kralja Petra I. kako u kolima s volovima napušta Srbiju, prvi put kao fotografije, zatim ilustracije u časopisu, pa onda razglednice i druge reprodukcije, imala je izniman odjek. Povijesni romani i uopće proza o Prvome svjetskom ratu često uzimaju kralja kao motiv. „Otuda će kralj Petar I sve više da se udaljava od istorijske ličnosti, jer u toj funkciji će sve manje biti, i ući će u krug mitologizovanih priča.” ${ }^{37}$ Odnosno: „Odiseja kralja i naroda sa srpskom vojskom jedna je od najizraženijih slika koje su se mogle stvoriti, a pečat izgnanstva i spasenja daje starozavetna vizija ratne kataklizme, ali i životna istrajnost." ${ }^{38}$ Prototip svih tih prizora, odnosno, ,osnovni izraz ovoj sceni dao je Vladimir Becić", ${ }^{9}$ što je inspiriralo mnoge pisce koji nisu pripadali samo srpskoj književnosti, pa je tako Edmond Rostand napisao poemu Les quatre bœufs du roi Pierre (Četiri vola kralja Petra) koja je trebala biti dijelom romantične drame posvećene srpskome kralju. U svojoj studiji posvećenoj kralju Petru I. Karađorđeviću Igor Borozan, osim doslovnih, otkriva niz simboličnih značenja ovog Becićeva prikaza staroga kralja. Ističe kako prikaz nacionalnog vladara na kolima s volovskom zapregom treba naglasiti da je on prvi među jednakima. Nadalje, ustrajnost iscrpljenih životinja koje vuku kola simbolizira otpornost i izdržljivost srpske krune i naroda, a prikaz kralja s udaljenosti naglašava krhkost njegova tijela. Jednom riječju, Becićevo djelo shvaćamo kao „simboličan prikaz odlučnosti i moći srbijanskog kralja i njegova naroda, utkane u arhetipske slike snažnih i nepokolebljivih volova". ${ }^{40}$

Koliko se Becićev prikaz kralja Petra I. duboko usadio u opći imaginarij govori i jedan vremenski bliži primjer. Američki redatelj srpskoga podrijetla Peter Bogdanovich radio je, u mlađim danima, intervju s velikim Johnom Fordom koji ga je pitao je li on Srbin te dodao: „Srbi imaju jednu fotografiju koja je gotovo film. Postoji iz Prvog svetskog rata ratna fotografija starog kralja Petra kako se na volovskim kolima 1915. povlači preko Kosova. I kada bi se taj kadar odmrznuo i pokrenuo, pred nama bi bio pravi pravcati film o velikoj drami srpskog naroda i njegovog kralja." ${ }^{41}$ Citirajući tu Fordovu
He would shoot and publish in the same magazine another photo of the king in exile, but this time in a wagon drawn by four thin, starving oxen. This photograph would serve as a template for a watercolour (I9I7), which he would subdue in a compositional sense and bring to a regular rhythm and spatial articulation. Nevertheless, the watercolour was only the groundwork for a large-format oil painting, and even that was supposed to be just a template for an even more representative work, a fresco. Everything in the watercolour, and this is even more obvious in the oil painting, takes place in an elongated frame, filled with several figures that are accompanying the king. These are no longer German prisoners nor recruited Serbian youths, not even peasants who are following their king. True, here we also find peasants, on the far right of the frame, but they are well-fed and nicely dressed. We find a wounded soldier with a bandaged head behind the king, as well as some military leaders. In addition to the king who is sitting on the wagon, there are only eight male figures, who might be his retinue or might just be greeting him like the two peasants on the right-hand side, one in front and the other behind the oxen. Becić first showed this painting in late December of I9I9, at his first post-war exhibition at the Salon Ullrich in Zagreb.

\section{5}

Arhiv za likovne umjetnosti HAZU-a, Arhiv Salona Ullrich-Knjiga izložaba 1910.-1927.

36

G. S., „Vladimir Becić”, 140-141.

37

Stanojević, Portret narodnog kralja, 243.

38

Vuković, „Kralj Petar ide...”, 167.

39

Stanojević, Portret narodnog kralja, 243.

40

Borozan, „From Crowned Monarch to War King: The Images of King Peter I Karadjordjević in the Period Between 1904 and 1918”, 294. 41

Marjanović, „Istorija u žarištu objektiva”, 71.

42

Isto.

43

Isto.

44

Arhiv Vojnoistorijskog instituta, Beograd. Popisnik 6, kutija 63, fascikl 3, dokument 21/1, list 1.

45

Marjanović, „Istorija u žarištu objektiva”, 81.

46

Među velikim ratnim fotografima koji su djelovali u sastavu srpske vojske treba istaknuti i Sampsona Tchernoffa koji je fotografirao dok je s Drugom armijom prolazio kroz Crnu Goru i Albaniju te stigao na Krf i izložio te fotografije u lipnju 1916. u muzeju Royal Institute Galleries u Londonu. Izložba je bila otvorena dva mjeseca i snažno je odjeknula u javnosti. Usp. isto, 93.

47

Isto, 92.

48

Fotografija se nalazi u Vojnom muzeju u Beogradu. Inv. br. R-2181. 49

To je djelo slikarova kći gospođa Vera Velebit poklonila prije mnogo godina Vojnome muzeju u Beogradu. Riječ je o temperi i bajcu na papiru, $450 \times 585 \mathrm{~mm}$. Na poleđini gore desno: Vladimir Becić, „Vezirov most” na Crnom Drimu prelaz srbske vojske 1915. g. 
izjavu, Milena Marjanović dopunjuje je rečenicom u kojoj kaže kako je riječ o „fotografiji koju je snimio slikar i fotograf Vladimir Becić, objavljenu u januaru 1916. na naslovnoj strani francuskog lista L'Illustration". ${ }^{42}$ Kao svojevrsni zaključak, a zapravo uvod u svoju studiju, autorica ispravno zaključuje da „nije bilo fotografija i filmskih traka kojima su ovekovečene mnoge ličnosti i događaji iz oba balkanska rata i Prvog svetskog rata, istoriografija Vojske Kraljevine Srbije bila bi sadržajno znatno siromašnija od one s kojom se srećemo u istorijskim spisima". ${ }^{43}$

Značenje fotografije prepoznato je u srpskoj vojsci još u vrijeme rata pa je po uzoru na francusku vojsku načelnik štaba Vrhovne komande general Petar Bojović izdao 13. svibnja 1916. u Solunu naredbu da se organizira fotografska služba srpske vojske s preciznim uputama za njihov rad te da „bi po mogućnosti svaki puk i druga zasebna jedinica trebali imati po jednog fotografa". ${ }^{4}$ Šef Fotografske sekcije prilikom njezina osnivanja bio je Dragiša M. Stojadinović, kojem je po dolasku na Krf naređeno da ode u Rim i nabavi nužnu tehniku. ${ }^{45}$ Značenje fotografije kao važnoga propagandnoga sredstva rano se prepoznalo u srpskoj vojsci pa tijekom rata nastaje nekoliko velikih fotografskih imena. ${ }^{46}$ Među njima je nedvojbeno jedan od najvažnijih Rista Marjanović koji svojim radovima sudjeluje na izložbama ratnih fotografija u Parizu, Londonu i New Yorku. U Parizu je tako, u Louvreu, bio zapažen na svesavezničkoj izložbi koju je otvorio predsjednik republike Raymond Poincaré. Po nalogu srpske Vlade pak u Londonu je izradio i predao trideset velikih ratnih albuma namijenjenih za darove saveznicima. ${ }^{47}$ Zanimljivo je spomenuti kako je i Rista Marjanović fotografirao kralja Petra I. tijekom njegova povlačenja s vojskom. Snimio je kralja kako sa štabom Vrhovne komande pješice prelazi preko Vezirova mosta u Albaniji u studenome $1915 .{ }^{48}$ lako je riječ o odličnoj fotografiji, nije postigla onaj uspjeh kao Becićeve fotografije na kojima je kralj prikazan u kolima koja vuku volovi, a osobito ona na kojoj su upregnuta četiri vola. Sačuvan je inače jedan Becićev rad, ne fotografski, nego slikarski, s prikazom Vezirova mosta. ${ }^{49}$

35

Croatian Academy of Sciences and Arts' Fine Arts Archive, Archive of the Salon Ullrich-Knjiga izložaba 1910.-1927. [Records of exhibition I910-1927]. 36

G. S.," Vladimir Becić."

37

Stanojević, Portret narodnog kralja, 243.

38

Vuković, “Kralj Petar ide...,” I67.

39

Stanojević, Portret narodnog kralja, 243

40

Borozan, "From Crowned Monarch to War King: The Images of King Peter I Karadjordjević in the Period Between 1904 and 19I8," 294.
The very neat records of Mr Ullrich tell us that the exhibition featured 44 of Becić's artworks, from drawings and lithographies to oil paintings, and that 39 of them had been sold. The first on the list is exactly this painting, now called The king's retreat, and with a decidedly highest price. It was estimated at 25,000 krunas, while the next one, Self-portrait, was priced at and sold for I0,000 krunas, followed by The young Englishman, whose price was 6,000. The records further state that the painting The king's retreat was bought by Mr Stankovic from Subotica, the Self-portrait by Mrs E. Erlich, etc. ${ }^{35}$ Critics covered Becić's show and wrote very favourably about it. One piece commented on the The king's retreat: "The large painting is a study for a fresco: 'The king's retreat'; it is well-composed, but I suppose that many things will be changed once it is executed as a fresco. This is a representation of the king in retreat, not as a fugitive, but with an awareness that the victory is his. And it as so. The painting is mon umental, everything that is secondary is pushed to the background or serves only to highlight the main motif., 36

The fresco was never created, but the distribution of Becićss presentation of king Petar I. leaving Serbia in an oxcart, first as a photograph, then as magazine illustration, then a postcard and other reproductions, had an outstanding impact. Historical novels and other prose on the First World War often take the king as the motif. "Hence king Petar I was moving farther away from a historical figure, since he would perform that function less and less, and entered the circle of mythologised stories." ${ }^{37}$ In other words: "The odyssey of the king and the people with the Serbian army is one of the most distinctive images that could have been cre-ated, while the mark of exile and salvation gives an Old-Testament vision of a war-time cataclysm, but also of life's endurance." ${ }^{38}$ The prototype for all those images, or rather, "the fundamental expression of the scene was provided by Vladimir Becić," ${ }^{39}$ and it inspired many writers who did not belong only to Serbian literary circles. Thus Edmond Rostand wrote a poem Les quatre boeufs du roi Pierre [The four oxen of king Petar), that was supposed to be a part of a romantic drama dedicated to the Serbian king. In his study dedicated to king Petar I. Karađorđević, Igor Borozan discovered the literal, but also a number of symbolic meanings of Becić's depiction of the old king. He wrote that the presentation of the national ruler on an oxcart was supposed to highlight his status as the first among equals. Furthermore, the perseverance of exhausted animals that are pulling the cart symbolised the resilience and endurance of the Serbian crown and people, while the portrayal of the king from afar highlighted the frailty of his body. In other words, we understand Becić's work as a "symbolic representation of the determination and power of the Serbian king and his people, interwoven into archetypal figures of strong and unfaltering oxen." ${ }^{40}$

The fact that Becićs portrayal of king Petar I. become deeply embedded in the general imaginarium is also attested by a more contemporary example. In his younger days, the 
Becićeve fotografske, crtačke, pa i tekstovne kronike dramatičnih zbivanja na području Balkana koje je objavljivao u francuskome ilustriranom časopisu, zatim iste prizore realizirane u grafikama, crtežima i slikama izlagao na svojim poratnim izložbama, ostat će zapamćene mnogo godina kasnije kao dio njegova svestranog umjetničkog djelovanja. ${ }^{50}$ Međutim, tijekom ratnih godina $i$ aktivnoga angažmana na bojišnicama slikar je cijelo vrijeme vodio brigu o svojoj supruzi koja je, nakon Bitolja, pješice stigla do Soluna. Solun je tih ratnih godina bio prenapučen grad u kojemu su, osim brojnih izbjeglica, boravile mnoge vojske pa je život bio iznimno težak i složen. Nakon što je ovaj grad ušao u sastav grčke države, prema nekim je procjenama brojio oko 150000 stanovnika, od čega su brojčano prednjačili potomci sefardskih Židova koji su se u Solun doselili krajem 15. stoljeća, malo više od $50 \%$ stanovništa pripadalo je Grcima i Turcima, koji su bili gotovo izjednačeni, a bio je tu i niz manjih etničkih skupina. ${ }^{51}$ Govorilo se kako je Solun preko noći postao Babilon, tim više što su u grad počele pristizati vojske, francuska u čijem su sastavu bili pitoreskno odjeveni Zuavi sa svojim širokim svjetloplavim hlačama i crvenim prslucima, zatim Senegalci s ogromnim crvenim fesovima i Marokanci s turbanima na glavi. Britanski vojnici nosili su prepoznatljivu lijepo krojenu uniformu kaki boje, a najčešće su imali lulu u ustima, koja im je davala prepoznatljiv znak. ${ }^{52} \mathrm{U}$ britanskom su sastavu bili Hindusi, Australci, Novozelanđani i Škoti odjeveni u raznobojne kiltove. Talijani su bili upadljivi u svojim svjetlozelenim uniformama i elegantnim cipelama na kojima su im ostali zavidjeli.

Međutim, prije nego što je srpska vojska stigla u Solun, a s njom i velik broj izbjeglica, najteža im se drama već bila dogodila. Tijekom 1914. pa do listopada 1915. vodile su se teške bitke na Ceru, Kolubari, u istočnoj Bosni i Sandžaku u kojima je srpska vojska izvojevala pobjede, ali pod pritiskom njemačkih, austrougarskih i bugarskih oružanih snaga počela se povlačiti zajedno s brojnim stanovništvom prema jugu pa je tako zabilježeno kako se u Valjevu krajem 1914. nalazilo samo 300 mještana. ${ }^{53}$ Vojska i narod povlače se uglavnom pješice preko Crne Gore i Albanije prema Jadranskome moru. Kroz albanske gudure prolaze tijekom studenoga i prosinca u vrijeme velikih hladnoća i samo je ovdje 60000 ljudi ostavilo svoje kosti, ne računajući regrute rezervnog sastava stradale između Debra i Valone. ${ }^{54}$ Kada konačno stižu na more u Medovu, Drač, Skadar... tu je više od 100000 izbjeglica i dva puta više vojske, no to nije krajnji cilj povlačenja, nego in se prebacuje na Krf, odakle će u periodu od 12. travnja do 21. svibnja 1916. stići u Solun. Na Krfu je srpska vojska dobila britanske i francuske vojne uniforme i naoružana je francuskim oružjem. ${ }^{55}$ Becić crta vojnika u punoj ratnoj opremi i objavljuje taj crtež u magazinu L'Illustration (Le soldat serbe, dans son nouvel équipement - La casque porte, au lieu de notre grenade, l'aigle blanc de Serbie), navodeći, kao i uvijek, kako je po prirodi crtao dopisnik Vladimir Betzich iz srpske vojske. Zajedno s vojskom, u Solunu je smješten i štab Vrhovne komande, a tu je bilo i sjedište prijestolonasljednika Aleksandra Karađorđevića. $U$ srpnju iste godine u ovaj grad stiže i ruska vojska. Solun, dakle, u kratkome vremenu zaista
American director of Serbian origins Peter Bogdanovich did an interview with the great John Ford, who asked him if he was Serbian, and added: "Serbs have one photograph that is almost a movie. There is a war photograph from World War I of the old king Petar retreating on an oxcart from Kosovo in 19I5. If you were to unfreeze and start that frame, we would have an actual movie about the great drama of the Serbian people and its king." ${ }^{41}$ Quoting this statement from Ford, Milena Marjanović finished it by saying that this was a "photograph taken by the painter and photographer Vladimir Becić, published in January I9I6 on the cover of the French paper L'Illustration." 42 As a sort of a conclusion, but really an introduction to her study, the author rightly concluded that, "if there were no photographs and filmstrips which immortalised many figures and events from both Balkan Wars and World War I, the historiography of the Army of the Kingdom of Serbia would be considerably poorer in terms of content than the one we encounter in historical documents." ${ }^{43}$

The meaning of the photograph was recognised by the Serbian army already during the war, which is why the Chief of General Staff Petar Bojović, following the example of the French army, on the I3th May I9I6 in Thessaloniki gave an order to organise a photo service of the Serbian army, with precise instructions for its work, specifying that "if possible, every regiment and other units should have their own photographer." ${ }^{44}$ At the time of its founding, the photo section was headed by Dragiša M. Stojadinović who, upon coming to Corfu, was ordered to go to Rome and acquire the necessary equipment. ${ }^{45}$

50

To dobro ilustrira i jedna šaljiva pjesma objavljena u doba kada je odavno stekao izniman ugled kao slikar, profesor na Likovnoj akademiji, kao poznata javna osoba. Riječ je o pjesmi pod naslovom „Vladimir Becić” objavljenoj u humorističkome listu Koprive u rubrici „Naša pinakoteka”, koja glasi: „On, Vladimir Becić, širokijeh pleća, / sa bradom po tipu starinskih mornara / na goršatačko zdravlje naše rase sjeća, / a s dobrim smiješkom bolove obara. / Albansku je nekad maljao Golgotu, / bio ratni slikar za solunsku zonu, / obišao mnogu makedonsku kotu, / javljajuć se stalno L'Illustrationu.” Usp. AFERIM. „Vladimir Becić”.

51

Više o životu u Solunu tijekom Prvoga svjetskoga rata vidi u: Tomašević, Veliki rat i Solunski front-Svakodnevni život vojnika u Solunu, 55-78. 52

Godine 1920. Becić je naslikao portret Jove Besarovića s lulom u ustima, inače nećaka svoje supruge, a sina njezine sestre Stane. Portret mladića naslovio je Mladi Englez prisjećajući se možda i engleskih vojnika koje je viđao u Solunu i koji su, kao prepoznatljiv znak, imali lulu u ustima. 53

O povlačenju srpske vojske, a još više civilnoga stanovništva, vidi u: Bojić, "Putevi naroda-Srpske izbeglice u Prvom svetskom ratu”, 109. 54

Isto, 111.

55

Tomašević, Veliki rat i Solunski front-Svakodnevni život vojnika u Solunu, 58. 56

Isto, 72. 
postaje Babilonom, ali izvrgnut neprestanoj ratnoj opasnosti. U svakodnevni život Soluna spadao je i onaj koji se odvijao noću, osobito u dijelu grada poznatome kao Bara (današnja općina Vardaris), gdje se tijekom rata nalazio velik broj javnih kuća, a u periodu od 1915. do 1918. taj je dio grada pretvoren u najveći ozloglašeni kvart na Balkanu. ${ }^{56}$

41

Marjanović, "Istorija u žarištu objektiva," 7I.

42

Ibid.

43

Ibid.

44

Archive of the Institute of Military History, Belgrade. List 6, box 63, folder 3, document 2I/I, page I.

45

Marjanović, "Istorija u žarištu objektiva," 8I.

46

Among the great war photographers who were active in the Serbian military, we should also mention Sampson Tchernoff, who passed with the Second Army through Montenegro and Albania to arrive to Corfu, and showed those photographs in June I9I6 at the Royal Institute Galleries in London. The exhibition was opened for two months and had a strong public reception. Cf. ibid., 93.

47

Ibid., 92.

48

The photograph is kept in the Military Museum in Belgrade. Inv. no. R-2I8I. 49

This was the work that the painter's daughter, Mrs Vera Velebit, donated many years ago to the Military Museum in Belgrade. It is a tempera and wood stain on paper, $450 \times 585 \mathrm{~mm}$. On the back, in the right-hand corner: "Vladimir Becić," "Vezirov most" [Vizier's bridge] on Crni Drim, crossing of the Serbian army in 1915 .

50

This is nicely illustrated by a humorous poem published at the time when he already had an outstanding reputation as a painter, a professor at the Academy of Visual Arts, and as a public persona. It is a poem called "Vladimir Becić," published in the satirical paper Koprive in the column "Naša pinakoteka" [Our pinacotheca], and it goes: "On, Vladimir Becić, širokijeh pleća, / sa bradom po tipu starinskih mornara / na goršatačko zdravlje naše rase sjeća, / a s dobrim smijeskom bolove obara. / Albansku je nekad maljao Golgotu, / bio ratni slikar za solunsku zonu, / obišao mnogu makedonsku kotu, / javljajuć se stalno L'Illustrationu." See: AFERIM. "Vladimir Becić."

51

For more on the life in Thessaloniki during WWI, see: Tomašević, Veliki rat i Solunski front-Svakodnevni život vojnika u Solunu, 55-78.

52

In I920, Becić painted a portrait of Jova Besarović with a pipe in his mouth, who was his wife's nephew, son of her sister Stana. He called it The Young Englishman, maybe remembering British soldiers he used to see in Thessaloniki who were recognisable by the pipes they had in their mouths.
The significance of photography as an important propaganda tool was recognised early on by the Serbian army, which produced several important names during the war. ${ }^{46}$ Among them, arguably the most important is that of Rista Marjanović, whose work was exhibited in war photography shows in Paris, London and New York. He was thus noted at an exhibition of all allies in Louvre, Paris, which was opened by the President of the Republic Raymond Poincaré. In London, on the order of the Serbian government, he made and delivered thirty big war albums meant as a gift for the allies. ${ }^{47}$ It is interesting to mention that Rista Marjanović also photographed king Petar I. during his withdrawal with the army. He photographed the king, together with the Chiefs of High Command, crossing the Vizier's Bridge on foot in I9I5 in Albania. ${ }^{48}$ Although it is an excellent photograph, it did not achieve the same success as Becićs photos depicting the king in an oxcart, and especially the one where he is drawn by four oxen. Incidentally, one of Becić's preserved pieces, not photographic but a painting, depicts the Vizier's bridge. ${ }^{49}$

Becić's photographic, illustrative and even written chronicles of the dramatic events in the Balkans, which he published in the French illustrated magazine, then those same scenes realised in graphics, drawings and paintings, shown at his post-war exhibitions, will be remembered many years later as a part of his versatile artistic activities. ${ }^{50}$ However, during the war years and his active engagement on the battlefields, the painter spent that entire time worrying about his wife who, after leaving Bitolj, had walked to Thessaloniki. During those war years, Thessaloniki was an overcrowded city which, in addition to numerous refugees, housed many armies, which is why life was extremely difficult and complicated. After the town became part of Greece, some estimates put its population at I50,000, of which the most numerous were the descendants of Sephardic Jews who came to Thessaloniki at the end of the I5th century, a little over 50\% were Greeks and Turks in almost equal proportion, and there was also a number of smaller ethnic groups. ${ }^{51}$ It was said that Thessaloniki turned into Babylon overnight, even more so when the armies began to arrive, like the French army that included the picturesque Zuavi with their wide, light-blue trousers and red waistcoats, then the Senegalese with enormous red fezes, and the Moroccans with turbans on their heads. British soldiers wore characteristic, nicely-cut khaki uniforms, and usually had a pipe in their mouth that gave them a distinctive mark. ${ }^{52}$ The British forces included the Hindus, Australians, New Zealanders and Scots dressed in colourful kilts. The Italians were noticeable in their light-green uniforms and elegant shoes that were the envy of everyone else.

However, before the Serbian army got to Thessaloniki followed by a large number of refugees, the biggest tragedy had already struck. In I9I4 and up to October I9I5, there was heavy fighting on Cera, Kolubara, in eastern Bosnia and Sandžak in which the Serbian army was victorious, but 
Usred rata Vladimiru i Ljubi Becić rodila se (24. studenoga 1916.) prva kći Mira. Zbog težine života, ali i ratne opasnosti koja je neprestano prijetila Solunu Becićevi su odlučili napustiti nesigurnu ratnu zonu pa su se uz pomoć francuske mornarice preko Krfa prebacili u Nicu, gdje se Ljuba zaposlila u ljekarni kako bi mogla uzdržavati sebe i dijete. Becić je pak tijekom tog boravka u Francuskoj otišao u Pariz, namjeravajući izdati mapu ratnih grafika za koju je već bio izradio dvije litografije većih formata (Molitva i Naša Golgota). Na povratku se nakratko zadržao u Nici i tu izveo nekoliko akvarela, a onda se vratio na Solun priključivši se francusko-srpskoj misiji i nakon proboja fronte stigao do Sofije. Samo nekoliko dana prije samoga kraja rata, točnije 5. studenoga 1918., objavljuje svoj posljednji prilog u magazinu L'Illustration. ${ }^{57}$ was forced to retreat to the south under the pressure of German, Austro-Hungarian and Bulgarian forces. The army was followed by numerous civilians, so that Valjevo was recorded as having only 300 inhabitants left at the end of I9I4. ${ }^{53}$ The army and the people were withdrawing, mostly on foot, across Montenegro and Albania towards the Adriatic Sea. They passed through the Albanian gorges in November and December, during a bitter cold which took the lives of 6o, ooo people, not counting the recruits of the reserve forces who died between Debar and Valona. ${ }^{54}$ When they finally reached the sea at Medovo, Drač, Skadar... there were over Ioo,ooo refugees and twice as many army personnel. That was, however, not their final destination, they were transferred to Corfu from where they would, in the period between i2th April and 2ist May I9I6, reach Thessaloniki. At Corfu, the Serbian army received British and French military uniforms and French weapons. ${ }^{55}$ Becić drew a soldier in full battle gear and published it in L'Illustration (Le soldat serbe, dans son nouvel équipement - La casque porte, au lieu de notre grenade, l'aigle blanc de Serbie), stating, as always, that it was drawn in nature by the field correspondent Vladimir Betzich of the Serbian army. In addition to the army, the Serbian High Command was also in Thessaloniki, as was the headquarters of the crown prince Aleksandar Karađorđević. In July of the same year, the Russian army arrived in town. Thus, in a short time, Thessaloniki really turned into Babylon, but was under constant danger of war. Everyday life in the city also took place during the night, especially in a part of the city known as Bara (today Vardaris), which had many brothels; in the period from I9I5-I9I8, that part of town turned into the biggest, most notorious neighbourhood in the Balkans. ${ }^{56}$

In the midst of the war (24th November I9I6), Vladimir and Ljuba Becić welcomed a baby, their first daughter Mira. Because of the severity of life, but also the war which constantly threatened Thessaloniki, the Becić family decided to leave the uncertainty of the war zone. With the help of the French navy, they travelled through Corfu to Nice, where Ljuba got a job at a pharmacy so she could support herself and the baby. During that stay in France, Becic went to Paris, intending to publish a map of war graphics for which he already made two larger-format lithographs (Prayer and Our Golgotha). On the way back, he stayed briefly in Nice and did a couple of watercolours, and then returned to Thessaloniki by joining the French-Serbian mission, and went all the way to Sofia after a breakthrough in the Salonica front. Just a few days before the end of the war, specifically on the 5 th November I9I8, Becic published his last contribution in the L'Illustration magazine. ${ }^{57}$

57

Ovaj rad prethodno je objavljen kao dio autorova teksta u katalogu izložbe Vladimir Becić u Galeriji Klovićevi dvori u Zagrebu, 6.12.2018.-10.3.2019. te je za ovu prigodu prilagođen i dopunjen. Rad je financirala Hrvatska zaklada za znanost projektom IP-2018-01-9364 Umjetnost i država u Hrvatskoj od prosvjetiteljstva do danas. 


\section{POPIS LITERATURE / BIBLIOGRAPHY}

Ambrozić, Katarina. Nadežda Petrović. Beograd: Srpska književna zadruga, Jugoslavija publik, 1978.

Becić, Vladimir. „Die Kunstphotographien des Herrn Varnai”. Die Drau, 5. kolovoza/August 1912.

Becić, Vladimir. „Uspomene” [Memories]. Savremenik 24/11 (1931.): 51-54.

Betzich, Vladimir. „Comment se battent les derniers Serbes”. L'Illustration, 28. listopada/October 1916.

Bojić, Dušica. „Putevi naroda-Srpske izbeglice u Prvom svetskom ratu" [Paths of a Nation-Serbian Refugees in the First World War], 107-127. U/In: Slikari/ratnici/svedoci. Slikarstvo i fotografija u Srbiji 1914-1918., ur./ed. Žana Gvozdenović. Beograd: Srpska akademija nauka i umetnosti, Muzej savremene umetnosti, 2017.

Borozan, Igor. „From Crowned Monarch to War King: The Images of King Peter I Karadjordjević in the Period Between 1904 and 1918". Srpske studije 7 (2016.): 271-296.

Bulimbašić, Sandi. Društvo hrvatskih umjetnika „Medulić” (1908. -1919.), umjetnost i politika [The Association of Croatian Artists "Medulić" (1908-1919), Art and Politics]. Zagreb: Društvo povjesničara umjetnosti Hrvatske, 2016.

G.S., „Vladimir Becić”. Omladina. List za zabavu i pouku srednjoškolske mladeži 3/6 (1920.): 140-141.

Marjanović, Milena. „Istorija u žarištu objektiva” [History in the Focus of the Camera], 71-105. U/In: Slikari/ratnici/svedoci. Slikarstvo i fotografija u Srbiji 1914-1918., ur./ed. Žana Gvozdenović. Beograd: Srpska akademija nauka i umetnosti, Muzej savremene umetnosti, 2017.

Milčinović, Andrija. „Vladimir Becić”. Savremenik 7/6 (1912.): 391-392.

Nonevski, Boris. Makedonskata faza vo tvoreštvoto na Vladimir Becić [The Macedonian Period of Vladimir Becić's Art] [rukopis/manuscript].

Peić, Matko. Vladimir Becić. Osijek: Revija-Izdavački centar Radničkog sveučilišta „Božidar Maslarić”, 1987.

Popović, Bogdan. „Prva jugoslovenska umetnička izložba” [The First Yugoslav Art Exhibition]. Srpski književni glasnik 14/3 (1905.): 225-231.

Prelog, Petar. „Tragom afirmacije slikarstva Münchenskog kruga” [Following the Afirmation of Painting of the Munich Circle]. U/In: Zbornik međunarodnog simpozija Zagreb-München-Hrvatsko slikarstvo i Akademija likovnih umjetnosti u Münchenu, ur./ed. Irena Kraševac, Petar Prelog. Zagreb: Institut za povijest umjetnosti, 2011.

53

For more on the withdrawal of the Serbian army, and especially of the civilian population, see: Bojić, "Putevi naroda-Srpske izbeglice u Prvom svetskom ratu," Io9.

54

Ibid., III.

55

Tomašević, Veliki rat i Solunski front-Svakodnevni život vojnika u Solunu, 58 . 56

Ibid., 72 .

57

This paper was previously published as part of the author's text in the catalogue of the exhibition Vladimir Becić in the Klovićevi dvori Gallery in Zagreb, 6th December 20I8-Ioth March 20I9, and was amended for this occasion. This work has been fully supported by Croatian Science Foundation's funding of the project IP-20I8-OI-9364 Art and the State in Croatia from the Enlightenment to the Present.
Tomašević, Jasmina I. „Veliki rat i Solunski front-Svakodnevni život vojnika u Solunu" [The Great War and the Salonica Front-Everyday Life of Soldiers in Thessaloniki]. Srpske studije 7 (2016.): 54-78.

Tonković, Marija. „Slikari fotografi” [Painters-Photographers], 332-348. U/In: Fotografija u Hrvatskoj. Zagreb: Muzej za umjetnost i obrt, 1994

Tonković, Zdenko. Vladimir Becić. Zagreb: Društvo povjesničara umjetnosti SR Hrvatske, 1988.

Stanojević, Mališa. Portret narodnog kralja [Portrait of a People's King]. Beograd: Filološki fakultet, 2005.

„Vladimir Becić”. Narodna obrana, 18. srpnja/July 1913.

AFERIM. „Vladimir Becić”. Koprive: list za satiru i humor 27/4 (1930): 67.

Vuković, Vladeta. „Kralj Petar ide...” [King Petar goes...]. Stremljenja 31/10, 11-12 (1991.)

\section{ARHIVSKI IZVORI / ARCHIVAL SOURCES}

AAM-Pup, oznaka 105A5: Atelijer Meštrović-Muzeji Ivana Meštrovića, Zagreb. Pismo Vladimira Becića Ivanu Meštroviću (Osijek, 17. studenoga 1912.)

AC, MPs-P, 1915., f 3, r 19: Srbija, Arhiv Srbije, Beograd.

Arhiv Vojnoistorijskog instituta, Beograd. Popisnik 3, kutija 83, fascikl 2 , broj $10 / 25$, list 1 .

Arhiv Vojnoistorijskog instituta, Beograd. Popisnik 6, kutija 63, fascikl 3, dokument 21/1, list 1 .

Arhiv za likovne umjetnosti HAZU-a, Zagreb. Arhiv Salona Ullrich -Knjiga izložaba 1910.-1927.

Pedagoški muzej Srbije, Beograd.Umetničko-zanatska škola Beograd, Izveštaj za školsku godinu 1913-1914, Beograd, 1914., Nastavno osoblje, 5.

Pedagoški muzej Srbije, Beograd. Srpska kraljevska gimnazija u Bitolju, Izveštaj za 1913-1914. školsku godinu, Bitolj, 1914., 12, 16-17.

Privatni arhiv dr. Vladimira Velebita, Ženeva.

Vojni muzej, Beograd. Fotoarhiv, Ratni dopisnici, br. 959,19.

Vojni muzej, Beograd. Fotoarhiv, inv. br. R-2181. 